\title{
Globalization and Taxation: Theory and Evidence
}

\author{
Priya Ranjan \\ University of California, Irvine \\ pranjan@uci.edu
}

\author{
Giray Gozgor \\ Istanbul Medeniyet University, Istanbul \\ giray.gozgor@medeniyet.edu.tr
}

\begin{abstract}
We construct a theoretical model to capture the compensation and efficiency effects of globalization in a set up where the redistributive tax rate is chosen by the median voter. The model predicts that the two alternative modes of globalization- trade liberalization and financial openness- could potentially have different effects on taxation. We then provide some empirical evidence on the relationship between taxation and the alternative modes of globalization using a large cross-country panel dataset. We make a distinction between de jure and de facto measures of globalization and find a robust negative relationship between de jure measures financial openness and tax rates. There is no robust relationship between de facto measures of finanical openness and taxation. As well, the relationship between trade liberalization (both de jure and de facto measures) and tax rates is not robust and depends on the measures of taxation as well as the time period of analysis.

Key Words: Trade liberalization, capital market openness, redistributive taxation, median voter

JEL Classification Codes: F11, F21, F68, H11
\end{abstract}




\section{Introduction}

There is a large literature studying the consequences of globalization for welfare state. In an influential work, Rodrik (1997) highlights how increased capital mobility threatens the implicit contract between governments and working class whereby the former offers social insurance in exchange for greater globalization. Schulze and Ursprung (1999) provide a comprehensive survey of the early literature. They argue that the globalization debate with respect to fiscal policy can be reduced to two effects - the efficiency and the compensation effect. The efficiency effect refers to the fact that increased mobility of goods and factors of production will induce countries to lower taxes thereby lowering the ability to provide public goods. The compensation effect refers to the fact globalization may increase demand for social insurance programs by increasing inequality as well as volatility. ${ }^{1}$ This paper provides a theoretical model to formalize these offsetting effects in a unified framework and empirically studies the relationship between globalization and taxation.

In the theoretical model, labor income is distributed equally but capital income is distributed unequally. The median voter decides on the level of redistributive taxation. Factors of production are inelastic in supply, therefore, taxation doesn't distort factor supply. However, there are two checks on the extent of redistributive taxation. There is an administrative cost of taxation which implies that the rate of taxation is less than $100 \%$ even in the absence of capital mobility. In the presence of capital mobility, capital flight (or reduced capital inflow) acts as a further check on taxation. While the tax competition literature assumes perfect capital mobility so that post-tax returns to capital are equalized across countries, a key feature of our model is imperfect mobility of capital which allows us to do comparative statics with respect to the degree of capital mobility. In the absence of capital mobility, the impact of trade liberalization depends on whether the country is capital abundant or labor abundant. In a capital abundant country, trade liberalization increases the reward of capital and reduces the reward of labor thereby increasing inequality, and consequently the need for greater redistributive taxation. The opposite happens in a labor abundant country. With capital mobility, things change. An increase in capital mobility can affect both the capital exporting and capital exporting countries in a similar fashion. Given our assumption of source based taxation of returns to capital, in a capital exporting country, increased capital mobility makes redistributive taxation more costly becauses it increases capital flight. In a capital importing country, taxation of capital reduces capital inflows, which reduces the tax base.

While the literature generally talks about compensation and efficiency hypothesis informally, our theoretical model fromalizes these effects. More importantly, our model shows that different facets of globalization may have different implications for taxation. In particular, it suggests that trade liberalization and capital market openness could have different effects on taxation depending on country's comparative advantage and the whether

\footnotetext{
${ }^{1}$ We focus on inequality here while Rodrik (1998) provides a model where globalization increases volatility. See Rodrik(2018) for a recent discussion of these issues.
} 
the country experiences inflows or outflows of capital. Also, the median voter model that we use highlights the role of inequality in determining the impact of globalization on taxation. In particular, the impact of globalization on taxation is likely to be stronger the greater the inequality.

Empirically, we study the relationship between globalization and taxation using a large cross-country panel data set. Unlike previous studies on globalization and taxation which have focused mainly on the OECD (Organization for Economic Cooperation and Development) countries our data set includes more than 100 countries including many developing countries which have undertaken capital account liberalization in the last couple of decades. We employ four alternative rates of taxation from two different sources. Top marginal income tax rate and top marginal income and payroll tax rate are obtained from the Economic Freedom Dataset of the Fraser Institute (see Gwartney et al. (2017)) and are available from 1970 to 2015. The corporate tax rate and the individual income tax rate obtained from KPMG are available from 2003 to 2015 . We use both de facto and de jure measures of trade liberalization and capital account liberalization but focus more on de jure measures because they are less likely to suffer from the endogeneity problem. We employ fixed effects regressions to focus on within country variations. Looking at the entire period 1970 to 2015 for which we have two measures of taxation available from the Economic Freedom Dataset, we find that all three de jure measures of capital account liberalization are strongly negatively associated with both rates of taxes. Our sole de jure measure of trade liberalization is significantly negatively related with the two measures of taxation as well. Looking at the sub-period 2003-2015 we find that the two KPMG measures of taxation are negatively associated with capital account liberalization but not with measures of trade liberalization. Checking the relationship between globalization and the two measures of taxation from the Economic Freedom dataset for the sub-period 2003-2015 we find a similar pattern. That is, the two tax rates are negatively associated with our de jure measures of capital account liberalization but not so with our de jure measure of trade liberalization. These baseline results are subjected to a number of robustness checks. We do not find a robust relationship between taxation and de facto measures of globalization (either capital account or trade). We also try to estimate if the impact of trade liberalization on taxation depends on the capital abundance of the country, as predicted by the theoretical model. Relying solely on across country variation, we do find some results consistent with the theoretical model that trade liberalization increases taxation in more capital abundant countries and decreases taxation in less capital abundant countries. However, the results become insignificant in the fixed effect estimation with country fixed effects. Also, seeing if the impact of globalization on taxation depends on inequality, in line with theory, we mostly find statistically insignificant results.

The remainder of the paper is organized as follows. In the next section we provide a brief summary of the related literature. Section 3 provides the theoretical model and section 4 provides empirical results. Section 5 provides some concluding remarks. 


\section{Related Literature}

Our theoretical model is related to the enormous tax competition literature surveyed in Keen and Konrad (2013). While this literature focuses on the strategic interaction between countries in setting taxes in a world with free capital mobility, we construct a model of a small open economy with imperfect capital mobility to derive the implications of globalization (trade liberalization and capital market openness) for taxation. Most papers in this literature derive optimal taxation by maximizing the welfare of a representative individual but one paper in the tax competition literature, Lockwood and Markis (2006), uses a median voter approach to show that it is possible for the tax rate preferred by the median voter to increase with capital market integration than in a closed economy. To obtain this result they assume heterogeneous preferences for public goods in addition to the heterogeneous distribution of endowments. This gives rise to the possibility that the median voter after capital market integration has a stronger preference for public goods than the median voter in the closed economy. Our modeling of imperfect capital mobility is similar to that in Persson and Tabellini (1992) who construct a theoretical model to study the implications of European integration for taxation. They assume a convex cost of investing abroad so that even if the net returns abroad are higher, not all capital is invested abroad.

Also, while the main purpose of taxation in the tax comptition literature is public good provision, the motive in our model is redistribution. Since there is no heterogeneity among individuals in the standard tax competition models, the question of redistribution does not arise. In contrast, in our model the sole purpose of taxation is redistribution.

As far as the empirical literature is concerned, an early influential paper is Rodrik (1997) which studies the impact of trade openness (measured as trade-GDP ratio) on the Average Effective Tax Rate (AETR hereafter) in a panel of 18 OECD countries over the period 1965-1991 and finds a negative relationship. Several subsequent papers have studied the relationship between globalization and taxation using alternative measures of globalization as well as taxation. Schulze and Ursprung (1999) provide an excellent survey of the early literature.

More recently, Adam et al. (2013) provide a nice meta study of the research on capital taxation and globalization. Their key finding is that study characteristics related to the way capital taxation is measured (effective tax rate or statutory tax rate) do not exert any systematic impact on the results, but the study characteristics related to the measure of globalization used is a key determinant of the relationship between globalization and capital tax rates ${ }^{2}$. In particular, studies using either trade-GDP ratio or the globalization index developed by Quinn (1997) are more likely to report a negative relationship between globalization and capital taxation, while studies employing the KOF index of globalization developed by Dreher (2006a) are more likely to report a posi-

\footnotetext{
${ }^{2}$ They also point out that studies using tax revenues instead of tax rates generally find a positive relationship between globalization and taxation, however, tax revenues conflate the tax rate and the tax base. Revenues can grow with an unchanged tax rate if the tax base grows. Therefore, we do not discuss studies that use tax revenue as a dependent variable.
} 
tive effect of globalization on capital tax rates. To conserve space below we discuss only studies published after Adam et al. (2013).

Onaran and Boesch (2014) examine the impact of the KOF indexes of globalization on AETR for capital, labor and consumption in a panel data of 15 European Union (EU) countries as well as the panel data of 13 Central and Eastern European (CEE) countries over the period 1970-2007. They do not find a significant relationship between globalization and capital taxation or consumption taxation but there is a positive relationship between economic globalization and labor income taxation in the panel of $15 \mathrm{EU}$ countries. For the panel of $13 \mathrm{CEE}$ economies they find a positive relationship between economic globalization and capital taxation, a negative relationship for consumption taxation and no relationship for labor income taxation. They also find some differences among countries depending on the type of the welfare regime.

Mourmans (2016) focuses on the top Statutory Corporate Tax Rate (SCTR hereafter) and the top Personal Income Tax Rate (ITR hereafter) for a panel data of 34 OECD countries over the period 1981-2014 and finds a negative relationship between globalization measured by trade-GDP ratio and taxation. Swank (2016) uses trade-GDP ratio and FDI as measures of globalization and finds both these to have a negative effect on the AETR and the SCTR in a panel data of 18 capitalist democracies over the period 1982-2008.

Exbrayat (2017) adds a twist to the standard tax competition literature by using insights from the economic geography literature. The key idea is that in the presence of trade costs and agglomeration economies, firms prefer to locate in larger markets and therefore larger countries have lower tax elasticities (less to lose from a higher tax) and they can tax agglomeration economies. Using a panel of 26 OECD countries over the period 1982-2006 she finds that countries with higher market potential (larger market size) set higher corporate taxes. Trade liberalization, by increasing market size, facilitates higher corporate taxes. In her setting, tax rate of a country depends on the sizes of other countries and the market potential of own country. Tax rates in a country are more responsive to tax rates in larger countries and the market potential of own country in terms of attracting firms.

In contrast to the existing literature which has focused on the OECD countries we use a panel of 149 countries with a relatively long time-span (1970-2015). As well, we use not only the SCTR and the individual ITR, but also the top marginal income and the payroll tax rates as the benchmark tax rate measures. Additionally, we make a distinction between de jure and de facto measures of trade and capital openness and find that de jure measures of capital openness (and trade liberalization in some cases) are robustly negatively related with taxation but de facto measures are not. Therefore, one important contribution of our empirical exercise is to point out that it is important to make a distinction between de jure and de facto measures of globalization. We also use the KOF data like several other studies in the literature ${ }^{3}$. Unlike previous studies that use the KOF index of

\footnotetext{
${ }^{3}$ See Portrafke (2015) for a survey of studies using the KOF index of globalization.
} 
economic globalization which combines various de facto and de jure measures of trade liberalization and financial openness into a single measure, we use a recently released version of the KOF data (see Gygli et al. (2018)) which allows us to separately study the effects of de jure and de facto measures of trade liberalization and capital market openness. This is important because we find the effects of de jure measures to be different from de facto measures and the effect of capital market openness to be different from the effect of trade liberalization. We also use two additional de jure measures of financial openness: Chinn-Ito index of financial openness and an index of financial liberalization from Freedom House. The results are similar across these 3 alternative de jure measures of financial openness.

Our key dependent variable in the empirical exercise is the statutory tax rate. Ideally we would like to use a measure that captures the effective tax rate by taking into account the various deductions that may be available to individuals and corporations which reduce the effective rates below the statutory rates. Devereux et al. (2008) use measures such as Effective Marginal Tax Rate (EMTR) and Average Effective Tax Rate (AETR), however, the data to construct such measures are available only for the OECD countries. While we recognize this shortcoming of our empirical exercise, in our defense we would like to cite the meta study of Adam et al. (2013) which concludes that the results on the relationship between globalization and taxes do not depend on whether the studies use EMTR, AETR, or statutory rates.

\section{Theoretical Model}

Suppose a small economy produces two traded intermediate goods using two factors of production, capital and labor. The two intermediates are assembled into a non-traded final good which is taken as the numeraire. Everyone consumes the final good and the utility function is linear in the consumption of the final good. To keep things simple assume that $X$ is produced using only labor while $Y$ is produced using only capital with the following production functions ${ }^{4}$ :

$$
X=A_{x} L ; Y=A_{y} K
$$

Each individual owns one unit of labor and $k_{i}$ units of capital. There are $L$ individuals in the economy and the total amount of capital is $K=\sum_{i=1}^{L} k_{i}$. Denote the capital-labor ratio for the economy by $\bar{k} \equiv \frac{K}{L}$.

The non-traded final good $Z$ is produced using the following Cobb-Douglas production function:

$$
Z=\frac{A_{z} X^{\eta} Y^{1-\eta}}{\eta^{\eta}(1-\eta)^{1-\eta}}
$$

Denote the price of good- $i$ by $p_{i}$. We choose the non-traded final good, $Z$, as the numeraire: $p_{z}=1$. Given the

\footnotetext{
${ }^{4}$ What is required for the results is that one good is more capital intensive than the other, a key assumption in the Heckscher-Ohlin model. The extreme factor intensity assumption simplifies the algebra considerably without any loss of generality.
} 
above production function and competitive markets for all goods, we get

$$
p_{z}=\frac{1}{A_{z}} p_{x}^{\eta} p_{y}^{1-\eta}=1
$$

If we know the price ratio for the intermediate goods, $\frac{p_{y}}{p_{x}}$, we can determine $p_{x}$ and $p_{y}$ in terms of the numeraire from the above equation.

Denoting the real wage (in terms of the numeraire) by $w$ and the real rental of capital by $r$, competitive factor markets imply

$$
w=A_{x} p_{x} ; r=A_{y} p_{y}
$$

Hence, for a given $\frac{p_{y}}{p_{x}}, w$ and $r$ are determined from above.

Each final good producer takes the prices of intermediate goods as given. The demand for the two intermediate goods can be easily derived from (2) as follows.

$$
X_{d}=\frac{\eta Z}{p_{x}} ; Y_{d}=\frac{(1-\eta) Z}{p_{y}}
$$

where subscript $d$ denotes demand. The above demand functions imply the following relative demand for intermediate good $X$.

$$
\frac{X_{d}}{Y_{d}}=\frac{\eta p_{y}}{(1-\eta) p_{x}}
$$

If the country is in autarky (no trade or capital mobility), then the full employment of the two factors of production implies the following relative supply of the intermediate good $Y$.

$$
\frac{X_{S}}{Y_{S}}=\frac{A_{x} L}{A_{y} K},
$$

where subscript $S$ denotes supply. The autarky relative price of the intermediate goods $\frac{p_{y}}{p_{x}}$ is obtained by

$$
\frac{X_{d}}{Y_{d}}=\frac{X_{S}}{Y_{S}} \Rightarrow \frac{p_{y}}{p_{x}}=\frac{(1-\eta) A_{x} L}{\eta A_{y} K}
$$

The real prices, $p_{x}$ and $p_{y}$, are determined by (3), which in turn determine the factor prices $r$ and $w$ according to (4).

We are going to discuss two facets of globalization: trade liberalization and capital mobility. Trade in the model is going to be trade in intermediate goods, $X$ and $Y$. As is clear from (8) the relative intermediate goods prices depend on the relative endowments: the model has a Heckscher-Ohlin structure. Therefore, a more capital abundant country (high $K / L$ ratio) has a comparative advantage in the capital intensive intermediate good $Y$ (low $\frac{p_{y}}{p_{x}}$ ). Hence, opening up to trade for a capital abundant country is going to imply an increase in the relative price of $Y$. We are going to capture trade liberalization in the model by a change in the relative price of $Y$. This can be thought of as arising from a decrease in the non-tariff barriers to trade. ${ }^{5}$ For a capital abundant country

\footnotetext{
${ }^{5}$ To keep the model simple by abstracting away from tariff revenue issues, we think of trade liberalization as a decrease in the non-tariff barriers.
} 
trade liberalization is captured by an increase in the relative price of $Y$ while for a labor abundant country it is captured by a decrease in the relative price of $Y$.

Turning to capital mobility, capital owners can invest their capital domestically and earn a return of $r$ (before taxes) or invest abroad and earn a return of $r_{f}$ net of any foreign taxes paid. All taxation of capital income is source based as is common in practice. That is, the capital income can be taxed only in the country where it is used. Given the enforcement problems associated with residence based taxation of capital income, this is a reasonable assumption. The model economy imposes a proportional tax of $t$ on all income and engages in redistribution $^{6}$. Given the domestic tax rate, $t$, the net return from investing capital domestically is $(1-t) r$. So, if $r_{f}>(1-t) r$, capital owners would want to invest abroad. If investing abroad is costless (as is assumed in the tax competition literature), then if $r_{f}>(1-t) r$ all capital is invested abroad and therefore, equilibrium must involve $r_{f}=(1-t) r$. We assume instead that it is costly to invest abroad. In particular, there is a convex cost of investing capital abroad (similar to Persson and Tabellini (1992) and Sorensen (2004)). That is, if an individual with total amount of capital $k$ invests $k^{f}$ abroad, the cost of investment abroad is $\frac{1}{2} \beta\left(\frac{k^{f}}{k}\right)^{2} k$, where $\beta>0$ captures the degree of capital mobility. $\beta \rightarrow \infty$ captures the case when the economy prohibits international capital flows. A lower $\beta$ captures greater mobility of capital. Note that this cost of investing abroad is very similar to the cost of adjustment of investment in the macroeconomics literature.

While we develop the case of a capital exporting country in the text, the case of a capital importing country is discussed in the appendix. That is, we implicitly assume that we are in the range of parameters where the inequality $r_{f}>(1-t) r$ is satisfied ${ }^{7}$. The logic of the Heckscher-Ohlin model would suggest that if a country is capital abundant, then the returns to capital should be lower than abroad and hence there should be capital outflows from this country. However, there could be capital outflows even from a labor abundant country in world where countries have different technologies. To see this possibility in a simple way, assume that countries have different $A_{z}$ in (2). Now, even if a country is labor abundant, the returns to capital, $r$, could be less than abroad due to lower productivity. That is, for a given world relative price $\frac{p_{y}}{p_{x}}, p_{x}$ and $p_{y}$ both would be lower in a low $A_{z}$ country and consequently both $w$ and $r$ would be lower as well. ${ }^{8}$ A broader point is that trade liberalization doesn't necessarily equalize factor prices despite our extreme factor intensity assumption because productivities (captured by $A_{i}$ ) could differ across countries.

The tax rate in the economy is determined as in a standard median voter model. The model is solved in two stages. In the first stage the tax rate is determined by the preferred tax rate of the median voter. In the second stage decisions regarding investing capital abroad are made taking the tax rate as given. Given that

\footnotetext{
${ }^{6}$ Even though we have assumed identical taxes on labor and capital income, allowing differential taxation of labor and capital will not change the result because labor income is identically distributed while capital income is distributed unequally. Therefore, the burden of redistributive taxation must be borne by capital.

${ }^{8}$ See Trefler (1993) for evidence on lower returns to both labor and capital in developing countries.
} 
factor supplies are inelastic, there is no distortion arising from taxation and hence in the absence of capital mobility, the median voter will choose $t=1$ (assuming the median voter owns less capital than the capital-labor ratio for the economy) resulting in the complete equalization of post-tax income. This is clearly unrealistic, therefore, we introduce an administrative cost of taxation which puts a limit on the amount of taxation even in the absence of the possibility of capital flight. The administrative cost of taxation is also convex. If the tax rate is $t$, the administrative cost is $\alpha t^{2}$. The tax proceeds are redistributed to individuals in a lump sum fashion: Each individual receives a lump sum transfer of $g$.

Below we discuss the model in general terms with capital mobility and later we will discuss the case of trade liberalization without capital mobility by shutting down capital flows.

We first discuss the second stage problem where knowing the tax rate individuals decide on how much capital to invest domestically and how much to invest abroad. An individual with capital $k_{i}$ decides what fraction, $s$, to invest abroad so that the remaining fraction $1-s$ is invested domestically. The individual maximizes the expression below in the second stage taking $t$ and $g$ as given.

$$
\underset{0 \leq s \leq 1}{M a x}\left\{w(1-t)+g+(1-t) r(1-s) k_{i}+r_{f}\left(s-\frac{1}{2} \beta s^{2}\right) k_{i}\right\}
$$

The first order condition from above maximization yields

$$
s=\left(\frac{r_{f}-(1-t) r}{\beta r_{f}}\right)
$$

Our assumption on the cost of investing abroad ensures that $s$ is independent of $k_{i}$ which keeps the model simple. That is, all individuals invest the same fraction of their capital abroad. Given the cost of investment abroad, an investor would invest abroad only if $r_{f}>(1-t) r$, which we assume to be the case. Equation (9) also implies

$$
\frac{d s}{d t}=\frac{r}{r_{f} \beta}>0 ; \frac{d s}{d \beta}=-\frac{s}{\beta}<0
$$

That is, the higher the domestic tax rate, $t$, the greater the investment abroad and the higher the barriers to capital mobility, $\beta$, the lower the investment abroad. Since each individual invests the same fraction of capital stock abroad, the transfer per individual $g$ can be written as

$$
g=\left(t-\alpha t^{2}\right) \frac{w L+r(1-s) K}{L}=\left(t-\alpha t^{2}\right)(w+r(1-s) \bar{k},
$$

where $w L+r(1-s) K$ is the tax base and $\bar{k}=K / L$ is average capital stock per person.

Denote the capital ownership of the median voter by $k^{m}$. The median voter recognizes the two costs of taxation: the administrative cost and the erosion of tax base due to capital flight. Therefore, the preferred level of taxation of the median voter is given by the solution to the following maximization problem.

$$
\left.\underset{0<t<1}{\operatorname{Max}}\left\{w(1-t)+\left(t-\alpha t^{2}\right)(w+r(1-s) \bar{k})+(1-t) r(1-s) k^{m}+r_{f}\left(s-\frac{1}{2} \beta s^{2}\right) k^{m}\right)\right\}
$$


Since $s$ is chosen optimally in the second stage, the first order condition for the optimal choice of $t$ is

$$
r(1-s)\left(\bar{k}-k^{m}\right)-2 \alpha t(w+r(1-s) \bar{k})-\left(t-\alpha t^{2}\right) \frac{r^{2} \bar{k}}{r_{f} \beta}=0
$$

The first term in (12) can be thought of as the marginal benefit from taxation which comes from redistribution and therefore it is positive only if $\bar{k}>k^{m}$, that is when the median voter has less capital than the average which we assume to be the case. The next two terms can be thought of as the marginal cost of taxation where the first term captures the administrative cost and the second term captures the cost resulting from capital flight. That is, the median voter recognizes that a higher taxation leads to greater capital flight and hence a smaller tax base for redistribution. In the appendix we derive the second order condition for the optimal choice of $t$.

\subsection{Impact of trade liberalization on taxation}

It is instructive to discuss two special cases here. Suppose the country prevents any capital outflow. This can be captured by $\beta \rightarrow \infty$ in the model. In this case, (12) yields (noting that $s=0$ )

$$
t^{m}=\frac{r\left(\bar{k}-k^{m}\right)}{2 \alpha(w+r \bar{k})}
$$

That is, the rate of tax preferred by the median voter is increasing in the gap between the average capital and the median voter's capital (inequality) and decreasing in the administrative cost of capital, $\alpha$.

We can also use (13) to study the implications of trade liberalization in the absence of capital mobility. Let us capture trade liberalization by a parameter $\tau$ where $\tau$ captures trade barriers. Earlier we said that the small country takes the world relative price, $\frac{p_{y}}{p_{x}}$, as given and then domestic real prices $p_{x}$ and $p_{y}$ are determined by (3). In the presence of trade barriers, there will be a wedge between the world relative price $\frac{p_{y}}{p_{x}}$ and the effective domestic relative price. For example, if the country has non-tariff barriers restricting imports, then in a capital abundant country, the effective domestic relative price of $Y$ is going to be lower than the world price, and hence a reduction in trade barriers will increase the effective domestic relative price towards the world price $\frac{p_{y}}{p_{x}}$. So, a decrease in $\tau$ in a capital abundant country effectively increases $\frac{p_{y}}{p_{x}}$. With this in mind, using (13) obtain the following expression for the impact of trade liberalization on the preferred tax rate of the median voter.

$$
\frac{d t^{m}}{d \tau}=\left(\bar{k}-k^{m}\right) \frac{w r^{\prime}(\tau)-r w^{\prime}(\tau)}{2 \alpha(w+r \bar{k})^{2}} .
$$

In the expression above, $r^{\prime}(\tau)$ and $w^{\prime}(\tau)$ capture the impact of trade liberalization on the rental of capital and wage, respectively. Now, in a capital abundant (scarce) country trade liberalization implies $r^{\prime}(\tau)<(>) 0$ and $w^{\prime}(\tau)>(<) 0$ and therefore, $\frac{d t^{m}}{d \tau}<(>) 0$.

Intuitively, since trade liberalization in a capital abundant country increases inequality, it increases the demand for redistribution. Hence the redistributive taxation increases. If there is no capital mobility, this is the only effect of trade liberalization which is captured in (14). This can be thought of as the compensation effect mentioned earlier. 
The other special case is one where the administrative cost of taxation is zero. This can be captured by setting $\alpha=0$ in (12). In this case we get

$$
t^{m}=\frac{\left(r+r_{f}(\beta-1)\right)\left(\bar{k}-k^{m}\right)}{r\left(2 \bar{k}-k^{m}\right)}
$$

The effect of trade liberalization in this case is given by

$$
\frac{d t^{m}}{d \tau}=\frac{\left(\bar{k}-k^{m}\right)}{\left(2 \bar{k}-k^{m}\right)} \frac{r_{f}(1-\beta)}{r^{2}} r^{\prime}(\tau)
$$

That is, the sign of $\frac{d t^{m}}{d \tau}$ is same as the sign of $(1-\beta) r^{\prime}(\tau)$. Therefore, in a capital abundant country, trade liberalization increases taxation if $\beta<1$ and reduces taxation otherwise. To see the intuition clearly, write (12) for the $\alpha=0$ case as follows.

$$
\left(\bar{k}-k^{m}\right)=\frac{t r \bar{k}}{r_{f}(\beta-1)+(1-t) r}
$$

The left hand side roughly captures the marginal benefit of taxation while the right hand side roughly captures the marginal cost of taxation. The marginal cost is clearly decreasing in $\beta$. That is, the greater the capital mobility (the lower the $\beta$ ) the more costly the taxation. Now, an increase in $r$ reduces the marginal cost of taxation if $\beta<1$. Since the marginal benefit (in the form written in (17)) is unchanged, the impact on the tax rate depends on what happens to the marginal $\operatorname{cost}^{9}$. And hence, trade liberalization in a capital abundant country increases taxation if $\beta<1$.

The expression for $\frac{d t^{m}}{d \tau}$ in the general case (when $0<\beta<\infty$ and $\alpha>0$ ) is derived in the appendix and has an ambiguous sign. However, we numerically verify that the sign of $\frac{d t^{m}}{d \tau}$ is same as the sign of $(1-\beta) r^{\prime}(\tau)$. That is, the result obtained for $\alpha=0$ case holds more generally ${ }^{10}$.

The result is summarized below.

Result 1: The impact of trade liberalization on redistributive taxation depends on whether the country is capital abundant or labor abundant. In the former case, trade liberalization is likely to increase taxation by increasing inequality but in the latter case it is likely to decrease it.

\subsection{Impact of capital market openness on taxation}

Next, we look at the impact of a change in $\beta$ on redistributive taxation. Looking at the $\alpha=0$ case first, the expression for the tax rate preferred by the median voter is given by (15). Therefore,

$$
\frac{d t^{m}}{d \beta}=r_{f} \frac{\left(\bar{k}-k^{m}\right)}{r\left(2 \bar{k}-k^{m}\right)}>0
$$

\footnotetext{
${ }^{9}$ Note from (12) that the marginal benefit of taxation is $r(1-s)\left(\bar{k}-k^{m}\right)$ while the marginal $\operatorname{cost}$ is $t \frac{r^{2} \bar{k}}{r_{f} \beta}$ for $\alpha=0$. For clarifying the impact of a change in $r$ on taxation we have divided both the marginal benefit and the marginal cost by $r(1-s)$ so that only the right hand side of (17) depends on $r$.

${ }^{10}$ The results of the numerical exercises are available upon request.
} 
The result above implies that a reduction in $\beta$ leads to a lower redistributive taxation. That is, an increase in capital mobility reduces redistributive taxation. This happens because the marginal cost of taxation increases due to increased capital flight.

The expression for $\frac{d t^{m}}{d \beta}$ for the general case of $\alpha>0$ is derived in the appendix and it is proved that $\frac{d t^{m}}{d \beta}>0$. That is, for a capital exporting country it is analytically proved that a reduction in the cost of capital flows reduces redistributive taxation. Therefore, while the result for trade liberalization had some ambiguity, there is no such ambiguity with respect to capital mobility for a capital exporting country.

The case of the capital importing country is discussed in the appendix. There a crucial new element is the elasticity of capital inflows with respect to the capital mobility cost. The results are going to be sensitive to this elasticity. Assuming capital flows to be unitary elastic with respect to $\beta$ and concave in the return differential $\left(r(1-t)-r_{f}\right)$ it is shown that in the $\alpha \rightarrow 0$ case a decrease in $\beta$ reduces taxation. For the $\alpha>0$ case numerical examples verify that when $\alpha$ is small, a decrease in $\beta$ reduces taxation but for very large values of $\alpha$ it is possible that a decrease in $\beta$ increases the tax rate chosen by the median voter. We summarize the result below.

Result 2: A reduction in the cost of capital flows reduces redistributive taxation unambiguously in the capital exporting countries. The same result obtains in capital importing countries for low values of $\alpha$ (the cost of taxation), however, for large values of $\alpha$ it is possible for the tax rate to increase as the cost of capital flows decreases.

In sum, in a capital exporting country the possibility of greater capital flight constrains taxation while in a capital importing country the possibility of smaller capital inflows constrains taxation.

\subsection{Empirical Implications}

The results above suggest that while the impact of trade liberalization on redistributive taxation depends on the factor abundance of a country, the impact of capital account liberalization is likely to be similar across capital importing and exporting countries. We exploit this result in our empirical exercise. Also, note from expressions (14) and (18) that the implications of trade liberalization as well as capital market openness depend on $\bar{k}-k^{m}$ which can be thought of as a measure of inequality. In the empirical exercise we below we attempt to test the following predictions of the model.

1. Tax rate is likely to increase with trade liberalization in a capital abundant country and decrease with trade liberalization in a labor abundant country.

2. Capital market openness is likely to reduce taxation in both capital importing and capital exporting countries.

3. The impact of both trade liberalization and capital market openness depends on inequality. In particular, the impact of globalization on taxation is expected to be increasing in inequality. 


\section{Empirical Exercise}

Our aim is to empirically estimate the relationship between the two facets of globalization- trade liberalization and capital market openness- and taxation. To this end, we estimate equations of the following form.

$$
\text { Tax_rate }_{i t}=\gamma_{0}+\gamma_{1} \text { Globalization }_{i t}+\gamma_{2}^{\prime} \cdot X_{i t}+\gamma_{3} t+u_{i}+\varepsilon_{i t}
$$

where $X_{i t}$ is a vector of controls, $\gamma_{3}$ captures the time trend, and $u_{i}$ is the country fixed effect. That is, we are going to rely on within country variation in estimating $\gamma_{1}$, our chief parameter of interest. ${ }^{11}$

The existing literature has used both de jure and de facto measures of globalization to study the above relationship where de facto measures capture actual trade and capital flows such as trade-GDP ratio while de jure measures capture policy changes. De facto measures can serve as a proxy for the de jure measures because the two tend to move together but de jure measures capture policy changes as well as technological changes reducing the cost of trade and investment flows better and hence are closer to the theoretical model. Also, de jure measures are less subject to the reverse causality problem that would arise with de facto measures if changes in tax rates affect trade and capital flows. Therefore, we are going to focus on de jure measures but to facilitate comparison with the existing literaure, we provide estimates with de facto measures as well.

In addition to the regression in equation (19) above we also estimate the deeper predictions of the theoretical model showing the dependence of the impact of trade liberalization on a country's capital abundance and level of inequality. We capture these effects by entering the interaction of globalization with capital-labor ratio and inequality, respectively.

\subsection{Data}

Our dataset covers the period 1970 to 2015 and includes 149 countries. Our key dependent variable is the tax rate and we use 4 alternative measures of it: i) top marginal income tax rate (TMITR), ii) top marginal income and payroll tax rate (TMIPTR), iii) corporate tax rate (CTR), and iv) individual income tax rate (IITR). The first two are obtained from the Economic Freedom Dataset of the Fraser Institute (see Gwartney et al. (2017)), and are available from 1970. ${ }^{12}$ The last two are obtained from the KPMG's corporate tax rate table and individual tax rate table, respectively, and are available from 2003 to 2015 . The relevant tax rate in the theoretical model

\footnotetext{
${ }^{11}$ We report robust standard errors clustered at the country level. In such a case, the classical Hausman test has size distortions (Kaiser, 2015). Therefore, we run the cluster-robust Hausman test of Kaiser (2015) to test the validity of the fixed-effects estimations. According to the research note of Kaiser (2015), the cluster-robust Hausman test is robust to the size distortions that can be observed in the classical Hausman test when using robust standard errors.

${ }^{12}$ Note that the economic freedom data set reports data at five-year intervals for the period from 1970 to 2000 and annual since 2000 .
} 
is one on mobile factors such as capital and one may think that the individual tax rates are not applicable for mobile factors. However, highly skilled labor is mobile and therefore individual tax rates are relevant for mobile factors as well. Additionally, partnerships and private firms are also taxed at individual rates. The correlation between the three measures of income tax rates is very high but the correlation of these with corporate tax rates is not very high as is shown in table 2 .

Our main measure of trade liberalization is a de jure measure recently released by the KOF Swiss Economic Institute (see Gygli et al. 2018 for details) ${ }^{13}$. This measure is constructed from three variables: non-tariff barriers and compliance cost, average tariff rates, and income from trade taxes as a percentage of total revenue. We call this TLIB_dj_KOF. We also use their de facto measure of trade globalization which is constructed using the world bank data on trade in goods and services as a percentage of GDP to which it adds a measure of trade partner diversification. We call this TLIB_df_KOF. Additionally, we use trade-GDP ratio from other sources as alternative measures of de facto trade globalization. We use both the nominal trade openness (provided by the World Development Indicators (WDI) of the World Bank and the Penn World Table (PWT) (version 9.0) of Feenstra et al. (2015)) and the real trade openness (provided by the PWT version 9.0 of Feenstra et al. (2015)). The nominal trade openness is the nominal values of exports plus imports relative to nominal GDP. The measure from the World Bank is called TLIB_df_WB and the measure from the Penn World Table is called TLIB_df_PWT. Following Alcala and Ciccone (2004), we also use the real trade openness to capture the differences in the prices of non-traded goods in the poor countries. This is denoted by TLIB_df_Real.

Our main measure of capital market liberalization or financial liberalization is also a de jure measure. It is the latest version of the Chinn-Ito index developed by Chinn and Ito (2006 and 2008) and is denoted by KOPEN_dj_CI. The Chinn-Ito index is used as the benchmark indicator of financial openness by various empirical papers since the dataset covers the most countries and the time-span (e.g. Furceri and Loungani, 2018). The index is the first principle component of four IMF binary variables: foreign exchange regime, export proceeds, capital account and current account. The index is defined from 0 to 1 and a higher value of the index specifies a greater level of the financial openness. In addition, we use a de jure measure of financial liberalization from the KOF Swiss Economic Institute which is constructed using the Chinn-Ito index, the index of Jahan and Wang (2016) that is based on the same source, but includes a broader set of variables in the construction, and a third measure taken from Gwartney et al. (2017) which includes measures of the prevalence of foreign ownership and regulations of international capital flows. This index is denoted by KOPEN_dj_KOF. Our third measure of capital market liberalization is a de jure measure of financial openness obtained directly from Gwartney et al. (2017) and is denoted by KOPEN_dj_FI where FI stands for Fraser Institute the original source of Gwartney et al. (2017). .

\footnotetext{
${ }^{13}$ Also see Dreher (2006b) for details of the construction of the KOF indexes.
} 
In addition to the de jure measures discussed above we also use a de facto measure of financial globalization taken from KOF Swiss Economic Institute which is constructed using 5 different financial flows: Foreign direct investment, Portfolio investment, International debt International reserves, and International income payments. This measure is denoted by KOPEN_df_KOF.

Data on income inequality is from the standardized world income inequality database (SWIID) (version 6.0) of Solt (2016). Among the institutional variables, civil liberties ratings (index from 1 to 7 and 1 represents the most-free nations and 7 represents the least-free nations) come from the Freedom House while the level of institutionalized democracy (index from 0 to 10) and a measure of overall institutional quality (constraint on the power of the executive, an index from 1 to 7) are obtained from the Polity IV Annual Time Series provided by Marshall et al. (2017). Some of our other control variables such as per capita GDP, population, and capital-labor ratio are from PWT (version 9.0).

Table 1 provides summary statistics as well as data sources for the key variables. Table 2 provides the correlation matrix for the main variables used in the regressions. The correlations among the tax measures are positive, however, the corporate tax rate has a lower correlation with the other 3 measures of taxation. Also, in most cases the tax rates are negatively correlated with various measures of globalization. More interestingly, the correlation among alternative measures of globalization varies considerably and perhaps accounts for the wide ranging results obtained in the literature on the impact of globalization on dependent variables of interest. For example, the correlation between de jure and de facto measures of trade liberalization from KOF is a meagre 0.32. Simliarly, the correlation between the de jure and de facto measures of financial globalization from KOF is 0.43. The correlation between our three de jure measures of financial globalization is reasonably high and varies from a high of 0.86 between KOPEN_dj_CI and KOPEN_dj_KOF to a low of 0.49 between KOPEN_dj_KOF and KOPEN_dj_FI.

Figure 1 shows the time trend in our tax variables and the measures of financial and trade openness. In general we observe a declining tax rate over time and increasing openness along both trade and financial dimensions. We capture the declining tax rate over time using a time trend in our regressions.

\subsection{Empirical Results}

We begin our empirical exercise by estimating the relationship between taxation and our measures of trade and financial globalization. Later we also test whether the impact of globalization depends on the capital abundance of the country and the level of inequality in the country.

Tables 3 and 4 show the results of the baseline regressions with 2 alternative measures of taxation which are available for 1970-2015. The key explanatory variables of interest are trade openness and financial openness measures. The controls are per capita GDP and population. Each regression includes country fixed effects and time trends. In both tables, our de jure measure of trade liberalization, TLIB_dj_KOF is significantly nega- 
tively related with the tax rates. However, all three de facto measures of trade liberalization (TLIB_df_WB, TLIB_df_PWT, and TLIB_df_KOF) are insignificant. As far as the measures of financial openness are concerned, all three de jure measures of financial globalization are significantly negatively related with the tax rates in both tables. The sole de facto measure of financial globalization from KOF, KOPEN_df_KOF, has a negative coefficient in both tables 3 and 4 but is statistically significant only in table 4 .

Since 2 of our measures of taxation (CTR and IITR) are available only from 2003 onwards, to make the results comparable we run the regressions in tables 3-4 for the sub-period 2003-2015. The results are reported in tables 5 and 6 . The key difference from tables 3 and 4 is that TLIB_dj_KOF becomes insignificant now. As far as the financial globalization is concerned, all 3 de jure measures remain significant and now the de facto measure of financial globalization becomes significant for both measures of taxation.

Tables 7 and 8 use the two KPMG tax measures, CTR and IITR, as the dependent variable. The results in tables 7 and 8 are very similar to those in table 5 and 6 . Trade liberalization measures (both de jure and de facto) are insignificant except for the real trade openness, TLIB_df_Real, in table 7. Again, all financial liberalization measures, both de jure and de facto, are negative and significant.

Looking at the quantitative significance of our results, the coefficient of KOPEN_dj_CI in table 3, column VI, implies that a one standard deviation increase in capital openness reduces the top marginal tax rate by 3.14 percentage points (about 0.19 standard deviation). For KOPEN_dj_Fi, the estimates in column VII of table 3 suggest that a one standard deviation increase in capital openness reduces the top marginal tax rate by 6.2 percentage points (.37 standard deviation). The coefficient of our third measure of capital openness, KOPEN_dj_KOF in column VII implies that a one standard deviation increase in capital openness reduces the top marginal tax rate by 4.35 percentage points ( 0.26 standard deviation). As far as trade liberalization is concerned, the coefficient of TLIB_dj_KOF in column I implies that a one standard deviation increase in trade openness reduces the top marginal tax rate by 2.56 percentage points ( 0.15 standard deviation).

Therefore, our baseline regressions suggest a robust negative relationship between financial openness and tax rates. The relationship between trade liberalization and tax rates is insignificant for the sub-period 2003-15 but is significant for the period 1970-2015 for the two measures of taxation which are available for the whole period.

As mentioned earlier, our theoretical model suggested that the impact of trade liberalization on taxation depended on whether a country was capital abundant or labor abundant. In particular, trade liberalization is expected to increase the tax rate preferred by the median voter in a capital abundant country and reduce the tax rate preferred by the median voter in a labor abundant country. We test this prediction of the model by using the interaction of the capital-labor ratio with trade liberalization. We first attempted it in the fixed effects regressions similar to those run in tables 3-8. We didn't get any significant results, probably, due to a lack of enough within country variation in the capital-labor ratio. Therefore, following the approach of Dutt and Mitra (2002), we attempted to test this prediction in purely cross-sectional regressions relying on across country 
variation rather than within country variation. That is, we run the following cross-sectional regression.

$$
\bar{T}_{i}=\gamma_{0}+\gamma_{1} \overline{k_{i}}+\gamma_{2} \bar{G}_{i}+\gamma_{3} \bar{G}_{i} * \overline{k_{i}}+\gamma_{2}^{\prime} \cdot X_{i t}+\varepsilon_{i}
$$

where the bar over a variable indicates the time average, $\bar{T}_{i}$ is the tax rate, $\bar{G}_{i}$ is the measure of globalization, and $\overline{k_{i}}$ is the $\log$ of capital-labor ratio. When $\bar{G}_{i}$ is a measure of trade liberalization, we expect $\gamma_{3}>0$, that is trade liberalization should increase taxation in more capital abundant countries.

The results for the period 2003-2015 for which we have data on all tax measures are reported in table 9 where $G_{i}$ is our de jure measure of trade liberalization. Consistent with our expectations based on theory, we find $\gamma_{3}>0$ (and statistically significant) for all 4 measures of taxation in columns I-IV. The coefficient of trade liberalization in these regressions is $\gamma_{2}+\gamma_{3} \overline{k_{i}}$. Looking at the estimates of $\gamma_{2}$ and $\gamma_{3}$ in colum I for the top marginal tax rate we find that trade liberalization is associated with a reduction in the top tax rate if $\overline{k_{i}}<11.03$ and an increase in the tax rate if $\overline{k_{i}}>11.03$. It turns out that the average $\bar{k}$ across countries is also 11.03. That is, trade liberalization is positively associated with taxation in countries with above average capital-labor ratio and negatively associated with taxation in countries with below average capital-labor ratio. The cutoff capital-labor ratio based on estimates in columns II-IV is as follows: for the top marginal and payroll taxes in column II it is 10.13; for the corporate tax rate in column III it is 12.37 ; for the individual income tax rate in column IV it is $10.55 .{ }^{14}$

In columns V-VIII in table 9 we run similar regressions but instead of capital-labor ratio we use the interaction with the Gini coefficient of market income. That is, we run the following regressions.

$$
\bar{T}_{i}=\gamma_{0}+\gamma_{1} \overline{\text { Gini }_{i}}+\gamma_{2} \bar{G}_{i}+\gamma_{3} \bar{G}_{i} * \overline{\operatorname{Gini}_{i}}+\gamma_{2}^{\prime} \cdot X_{i t}+\varepsilon_{i}
$$

The theory is less clear cut here. It suggests that the impact of globalization (whichever direction it is) on taxation should be larger the greater the inequality. The estimates of $\gamma_{3}$ are generally insignificant.

In Table 10 we report the results of the regressions similar to those in table 9 but with de jure measure of financial openness (KOPEN) instead of trade liberalization. The results for the capital-labor ratio interaction in columns I-IV are qualitatively similar to those in columns I-IV in table 9 . Note that unlike trade liberalization, we do not have a clear cut theoretical prediction for how financial openness should interact with a country's capital abundance. However, the results suggest that even financial openness is positively associated with taxation in countries with high capital-labor ratio and negatively associated with financial openness in countries with low capital-labor ratio. The interaction with the Gini coefficient of market income also produces results similar to those in table 10. That is, the interaction coefficients are mostly insignificant.

\footnotetext{
${ }^{14}$ We ran panel regressions with country effects modeled as random instead of fixed and the results are very similar to those reported in table 9. We also ran OLS with repeated cross-sections and panel regressions exploiting just the between effects, and the results are qualitatively very similar to those reported in table 9. As mentioned earlier, when we run the fixed effects regressions, the interaction coefficients become insignificant. All these results are available upon request.
} 
Even though the results in columns I-IV of table 9 are consistent with the theoretical predictions of the model, it is worth recalling that these results relied on purely cross-sectional variation as in Dutt and Mitra (2002). Therefore, we have less confidence in the interaction coefficients based on cross-sectional regressions. In the remainder of the empirical exercise we ignore these interaction terms and conduct a series of robustness exercises for our baseline results on the relationship between taxation and globalization obtained using fixed effect estimation in tables 3-8. To avoid reporting too many regression results, we just focus on TLIB_dj_KOF and KOPEN_dj_CI as our measures of trade and financial globalization, respectively. Since TLIB_dj_KOF is significant for 1970-2015 for TMITR and TMIPTR, the regressions involving these tax measures are for the whole period 1970-2015, while the regressions involving the two KPMG measures CTR and IITR are for the period 2003-15.

\subsection{Robustness Exercise}

\subsubsection{Countries by level of Development}

Our first robustness exercise involves seeing if the results in the baseline regressions in tables 3-8 hold separately for lower income and higher income countries. This is important because most earlier studies have focused on the OECD countries (e.g. Kammas (2011)). We use the World Bank classification to classify countries into two groups: low-income and lower-middle-income if per capita income in year 2016 is below $\$ 3,956$ (66 countries); and upper-middle and high income if per capita income in 2016 is above $\$ 3,956$ (83 countries). The list of countries in each group is provided in the appendix. Table 11 reports the results for low and lower middle income countries. The results are qualitatively similar to those in the baseline regressions reported earlier. TLIB_dj_KOF is insignificantly related with the tax rates but KOPEN_dj_CI is significantly negatively associated with the tax rates except for the IITR where the coefficient has a negative sign but fails to be significant. In table 12 for upper middle and high income countries we find that TLIB_dj_KOF is significantly negatively related with TMITR and TMIPTR but not with IITR and CTR. KOPEN_dj_CI is significantly negatively related with 3 measures of tax rates and the coefficient for CTR is negative but fails to be significant. So, as far as financial openness measures are concerned, they are significantly negatively related with TMITR and TMIPTR for both groups of countries. However, KOPEN_dj_CI is significantly related with CTR but not IITR for low and lower middle income countries and with IITR but not CTR for for upper middle and high income countries. Tables 13 and 14 repeat the above exercise for non-OECD and OECD countries and results are qualitatively similar.

\subsubsection{Institutional Controls}

The theoretical model was based on a majoritarian government but in real world countries have very different political institutions. Therefore, we re-estimate our baseline regressions by controlling for some measures of 
institutional quality including political institutions. Following the spirit of Adam and Kammas (2007) and Acemoglu et al. (2018), we use the level of institutionalized democracy (index from 0 to 10) as a measure of the quality of democratic institutions. Following, Gozgor and Ranjan (2017), we also use the civil liberties ratings (index from 1 to 7 where 1 represents the most-free nations and 7 represents the least-free nations). In addition, we include a measure of the constraint on the executive (index from 1 to 7 ) as a measure of overall institutional quality. The results with these controls are reported in table 15. In each regression reported in table 15 our baseline controls-per capita GDP, population, time trend, and country fixed effect-are included but not reported to save space. The results are in line with the results in the baseline regressions reported in tables $3-8$. To facilitate comparison with the baseline estimates, the first row in each panel reproduces the baseline estimates. For TMITR and TMIPTR the estimates are from tables 3-4 while for CTR and IITR they are from tables 7 and 8 , repsectively. The inclusion of these institutional controls does not change the coefficients by much.

\subsubsection{Robustness to the Outliers/regions}

Tables 16 provides the results of additional robustness checks by excluding the outliers and specific countries from the dataset. The first set of robustness checks considers excluding the extreme observations for the measures of the tax rates, TLIB_dj_KOF, and KOPEN_dj_CI. Following Gozgor and Ranjan (2017) and Furceri and Lougnani (2018), we identify the extreme observations as those which are more than two standard deviations away from the average. The results are robust to the exclusion of extreme observations from the dataset.

Next we check whether the effects of globalization on tax rates are driven by particular regions by excluding one region at a time. More precisely, following the spirit of the empirical analyses in Rodrik (1998) and Gozgor and Ranjan (2017), we exclude the observations for the Sub-Saharan African, the Latin American and the Caribbean as well as the developing East Asian countries, one region at a time. The results in Table 16 are robust to the exclusion of each region, one at a time, and this implies that the baseline results are not dominated by the presence of observations from any specific region.

Overall, various robustness checks indicate that the results obtained in the baseline regressions in tables 3-8 are robust. That is, financial openness is significantly negatively related with all 4 measures of taxation. Trade liberalization is significantly negatively related with TMITR and TMIPTR but not with IITR and CTR. However, as was revealed in the comparison of tables 3-4 with 5-6, the trade liberalization measure loses statistical significance even for TMITR and TMIPTR for the sub-period 2003-15.

\section{Concluding Remarks}

This paper constructed a theoretical model to capture the opposing compensation and efficiency effects of globalization in a set up where the redistributive tax rate is chosen by the median voter. The model predicted that 
trade liberalization and financial openness could potentially have different effects on taxation depending on the comparative advantage of a country. The paper then provided some empirical evidence on the relationship between various measures of taxation and two alternative modes of globalization- trade liberalization and financial openness-using a large cross-country panel dataset. The paper made a distinction between de jure and de facto measures of globalization and found a robust negative relationship between de jure measures financial openness and tax rates but the relationship between trade liberalization and tax rates was not robust and depended on the measures of taxation as well as the time period of analysis.

\section{Appendix}

\subsection{Derivation of Second order condition}

Denote the first order condition with respect to $t$ given in (12) in the text by $\Psi(t, \alpha, \beta, \tau)=0$ where $\tau$ captures trade liberalization in the text. Now, the second order condition for the objective function to be concave in $t$ is $\Psi_{t}<0$.

From the expression for $\Psi(t, \alpha, \beta, \tau)$ in the text obtain

$$
\Psi_{t}=-2 \alpha(w+r(1-s) \bar{k})-(1-4 \alpha t) \frac{r^{2} \bar{k}}{r_{f} \beta}-r\left(\bar{k}-k^{m}\right) \frac{r^{2}}{r_{f} \beta}
$$

A sufficient condition for $\Psi_{t}<0$ is $\alpha<\frac{1}{4 t}$ which looks plausible. We numerically verify that this condition is easily satisfied for reasonable values of other parameters.

\subsection{Impact of trade liberalization in the general case}

To find out the impact of trade liberalization on the preferred tax of the median voter, obtain the following from the first order condition $\Psi(t, \alpha, \beta, \tau)=0$.

$$
\Psi_{t} \frac{d t}{d \tau}+\Psi_{\tau}=0
$$

Therefore,

$$
\frac{d t}{d \tau}=-\frac{\Psi_{\tau}}{\Psi_{t}}
$$

Since $\Psi_{t}<0$, the sign of $\frac{d t}{d \tau}$ is same as the sign of $\Psi_{\tau}$. Now, $\tau$ affects the endogenous variables of interest through $w$ and $r$. Therefore, using (12) obtain the following expression for

$\Psi_{\tau}=-2 \alpha t\left(w^{\prime}(\tau)+r^{\prime}(\tau)(1-s) \bar{k}\right)-2\left(t-\alpha t^{2}\right) \frac{r}{r_{f} \beta} \bar{k} r^{\prime}(\tau)+(1-s)\left(\bar{k}-k^{m}\right) r^{\prime}(\tau)+\left(r\left(\bar{k}-k^{m}\right)-2 \alpha t r \bar{k}\right) \frac{(1-t)}{r_{f} \beta} r^{\prime}(\tau)$

It is straightforward to verify that for $\beta \rightarrow \infty$ the expression for $\frac{d t}{d \tau}$ converges to that in (14) in the text and for $\alpha=0$ it converges to (16). For the more general case we verify numerically that the sign of $\Psi_{\tau}$ is same as the $\operatorname{sign}$ of $r^{\prime}(\tau)$. 


\subsection{Impact of capital mobility in the general case}

From the first order condition (12) in the text denoted by $\Psi(t, \alpha, \beta, \tau)=0$ obtain the following expression for $\Psi_{\beta}$

$$
\Psi_{\beta}=\left(t-\alpha t^{2}\right) \frac{r^{2} \bar{k}}{r_{f} \beta^{2}}+\left[r\left(\bar{k}-k^{m}\right)-2 \alpha t r \bar{k}\right] \frac{s}{\beta}
$$

Next, verify that $r\left(\bar{k}-k^{m}\right)-2 \alpha t r \bar{k}>0$. This can be verified as follows. $\Psi(t, \alpha, \beta, \tau)=0$ implies

$$
r(1-s)\left(\bar{k}-k^{m}\right)=2 \alpha t(w+r(1-s) \bar{k})+\left(t-\alpha t^{2}\right) \frac{r^{2} \bar{k}}{r_{f} \beta}
$$

which in turn implies

$$
r\left(\bar{k}-k^{m}\right)=2 \alpha t\left(\frac{w}{1-s}+r \bar{k}\right)+\left(t-\alpha t^{2}\right) \frac{r^{2} \bar{k}}{r_{f} \beta(1-s)}
$$

Therefore, $r\left(\bar{k}-k^{m}\right)>2 \alpha t r \bar{k}$, and hence, $\Psi_{\beta}>0$.

Next, from the definition of $\Psi$ we obtain

$$
\Psi_{t} \frac{d t^{m}}{d \beta}+\Psi_{\beta}=0
$$

Therefore,

$$
\frac{d t^{m}}{d \beta}=-\frac{\Psi_{\beta}}{\Psi_{t}}
$$

Since $\Psi_{t}<0$ is the second order condition for the optimization, we obtain $\frac{d t^{m}}{d \beta}>0 . Q E D$.

\subsection{Appendix B: Taxation with capital inflows}

Suppose we are in the range where $r(1-t)>r_{f}$. In this case there is capital inflow into the country. Denote the amount of capital inflow by $K^{I}$. In this scenario the median voter maximizes

$$
\underset{0<t<1}{\operatorname{Max}}\left\{(1-t)\left(w+r k^{m}\right)+\left(t-\alpha t^{2}\right)\left(w+r\left(\bar{k}+k^{I}\right)\right)\right\}
$$

where $k^{I}=\frac{K^{I}}{L}$. The first order condition is

$$
r\left(\bar{k}+k^{I}-k^{m}\right)-2 \alpha t\left(w+r \bar{k}+r k^{I}\right)+\left(t-\alpha t^{2}\right) r \frac{d k^{I}}{d t}=0
$$

In the $\alpha=0$ case the first order condition above can be written as

$$
\left(\bar{k}-k^{m}+k^{I}\right)=-t \frac{d k^{I}}{d t}
$$

So, for the median voter in a country receiving capital inflows, the marginal benefit of taxation is the tax base which includes foreign capital. The marginal cost of taxation is a reduction in the foreign capital inflows.

(29) implies

$$
t^{m}=\frac{\left(\bar{k}-k^{m}+k^{I}\right)}{-\frac{d k^{I}}{d t}}
$$


Also, for the maximization problem to be concave we need

$$
2 \frac{d k^{I}}{d t}+t \frac{d^{2} k^{I}}{d t^{2}}<0
$$

Assume the following functional form for $k^{I}$.

$$
k^{I}=\frac{\gamma}{\beta} f\left(r(1-t)-r_{f}\right) ; f^{\prime}>0, f^{\prime \prime}<0 .
$$

That is, the capital inflows are positively related to the net return and negatively related to the capital market openness parameter $\beta$. Next, obtain the following from (32).

$$
\frac{d k^{I}}{d t}=-r \frac{\gamma}{\beta} f^{\prime}<0 ; \frac{d^{2} k^{I}}{d t^{2}}=r^{2} \frac{\gamma}{\beta} f^{\prime \prime}<0 ; \frac{d^{2} k^{I}}{d t d \beta}=r \frac{\gamma}{\beta^{2}} f^{\prime}+r^{2} \frac{\gamma}{\beta} f^{\prime \prime} \frac{d t}{d \beta} .
$$

Verify that $f^{\prime}>0, f^{\prime \prime}<0$ is sufficient for the inequality in (31) to be true.

Next, take the derivative of $(29)$ with respect to $\beta$ to obtain

$$
\frac{d k^{I}}{d \beta}-\left(r \frac{\gamma}{\beta} f^{\prime}\right) \frac{d t^{m}}{d \beta}+\operatorname{tr} \frac{\gamma}{\beta^{2}} f^{\prime}+t^{2} \frac{\gamma}{\beta} f^{\prime \prime} \frac{d t^{m}}{d \beta}=0
$$

Next, note from (32) that

$$
\frac{d k^{I}}{d \beta}=-\frac{k^{I}}{\beta}-r \frac{\gamma}{\beta} f^{\prime} \frac{d t^{m}}{d \beta}
$$

Using (35) in (34) obtain

$$
\frac{d t^{m}}{d \beta}=\frac{k^{I}-t r \frac{\gamma}{\beta} f^{\prime}}{t r^{2} \gamma f^{\prime \prime}-2 r \gamma f^{\prime}}
$$

Note that $\operatorname{tr}^{2} \gamma f^{\prime \prime}-2 r \gamma f^{\prime}<0$ is the second order condition in (31), therefore, the denominator above is negative.

It turns out that the numerator is also negative. To see this note that $-\operatorname{tr} \frac{\gamma}{\beta} f^{\prime}=t \frac{d k^{I}}{d t}$. Therefore, the numerator becomes $k^{I}+t \frac{d k^{I}}{d t}$ which is negative as can be verified from (29). Therefore, $\frac{d t^{m}}{d \beta}>0$.

In the general case of $\alpha>0$ we obtain the following expression using (28),(32), (33) and (35).

$$
\frac{d t^{m}}{d \beta}=\frac{r}{\beta} \frac{(1-2 \alpha t) k^{I}-\left(t-\alpha t^{2}\right) \frac{r \gamma}{\beta} f^{\prime}}{\left(-2(1-2 \alpha t) r^{2} \frac{\gamma}{\beta} f^{\prime}-2 \alpha\left(w+r \bar{k}+r k^{I}\right)+\left(t-\alpha t^{2}\right) r^{3} \frac{\gamma}{\beta} f^{\prime \prime}\right)}
$$

Verify from above that for $\alpha=0$ the above reduces to (36). Next, verify that the denominator above is negative because $f^{\prime}>0$ and $f^{\prime \prime}<0$. The sign of the numerator is ambiguous. Also, using (28) and the expression for $\frac{d k^{I}}{d t}$ from (33) note that the numerator is simply $r\left(k^{m}-\bar{k}\right)+2 \alpha t(w+r \bar{k})$. Since $k^{m}<\bar{k}$ by assumption, the numerator is negative for small values of $\alpha$. We numerically verify that for large values of $\alpha$ the numerator becomes positive.

\section{References}

[1] Acemoglu, D., Naidu, S., Restrepo, P., \& Robinson, J.A. (2018). Democracy does cause growth. Journal of Political Economy. 
[2] Adam, A., \& Kammas, P. (2007). Tax policies in a globalized world: is it politics after all? Public Choice, $133(3-4), 321-341$.

[3] Adam, A., Kammas, P., \& Lagou, A. (2013). The effect of globalization on capital taxation: What have we learned after 20 years of empirical studies? Journal of Macroeconomics, 35, 199-209.

[4] Alcalá, F., \& Ciccone, A. (2004). Trade and Productivity. The Quarterly Journal of Economics, 119 (2), 613-646.

[5] Chinn, M.D., \& Ito, H. (2006). What matters for financial development? Capital controls, institutions, and interactions. Journal of Development Economics, 81 (1), 163-192.

[6] Chinn, M.D., \& Ito, H. (2008). A new measure of financial openness. Journal of Comparative Policy Analysis: Research and Practice, 10 (3), 309-322.

[7] Devereux, M.P., Lockwood, B., \& Redoano, M. (2008). Do countries compete over corporate tax rates? Journal of Public Economics, 92 (5-6), 1210-1235.

[8] Dreher, A. (2006a). The influence of globalization on taxes and social policy: An empirical analysis for OECD countries. European Journal of Political Economy, 22 (1), 179-201.

[9] Dreher, A. (2006b). Does globalization affect growth? Evidence from a new index of globalization. Applied Economics, 38 (10), 1091-1110.

[10] Dutt, P. and D. Mitra. (2002). Endogenous trade policy through majority voting: an empirical investigation, The Journal of International Economics, 58, 107-133.

[11] Dutt, P. and D. Mitra. (2005). Political ideology and endogenous trade policy: an empirical investigation, The Review of Economics and Statistics, 59-72.

[12] Exbrayat, N. (2017). Does trade liberalisation trigger tax competition? Theory and evidence from OECD countries. The World Economy, 40 (1), 88-115.

[13] Feenstra, R.C., Inklaar, R., \& Timmer, M.P. (2015). The next generation of the Penn World Table. The American Economic Review, 105 (10), 3150-3182.

[14] Furceri, D., \& Loungani, P. (2018). The distributional effects of capital account liberalization. Journal of Development Economics, 130, 127-144.

[15] Gozgor, G., \& Ranjan, P. (2017). Globalisation, inequality and redistribution: Theory and evidence. The World Economy, forthcoming. 
[16] Gwartney, J., Lawson, R., \& Hall, J. (2017). Economic Freedom of the World: 2016 Annual Report. Fraser Institute: Vancouver, BC.

[17] Gygli, S., Haelg, F., \& Sturm, J.E. (2018): The KOF Globalisation Index - Revisited. KOF Working Paper, No. 439.

[18] Jahan, S., \& Wang, D. (2016). Capital Account Openness in Low-income Developing Countries; Evidence from a New Database. International Monetary Fund Working Paper, No. 16/252, International Monetary Fund: Washington, D.C.

[19] Kaiser, B. (2015). RHAUSMAN: Stata module to perform robust Hausman specification test. Software component provided by Boston College Department of Economics, Number: S457909.

[20] Kammas, P. (2011). Strategic fiscal interaction among OECD countries. Public Choice, 147 (3-4), 459-480.

[21] Keen, M., \& Konrad, K.A. (2013). "The Theory of International Tax Competition and Coordination", A.J. Auerbach, R. Chetty, M. Feldstein, \& E. Saez (Eds.) Handbook of Public Economics, Volume 5, (pp. 257-328), Elsevier: Amsterdam.

[22] Lockwood, B., \& Makris, M. (2006). Tax Incidence, Majority Voting and Capital Market Integration. Journal of Public Economics, 90 (6-7), 1007-1025.

[23] Marshall, M.G., Gurr, T.R., and Jaggers, K. (2017). Polity IV Project: Political Regime Characteristics and Transitions, 1800-2015. Center for Systemic Peace: Vienna, VA.

[24] Mourmans, N.J. (2016). What drives the decreasing corporate tax rates? An empirical research on tax competition. Research in Business and Economics, MaRBLE Research Papers, Volume 2, 2016 Edition, $1-21$.

[25] Onaran, O., \& Boesch, V. (2014). The effect of globalization on the distribution of taxes and social expenditures in Europe: Do welfare state regimes matter? Environment and Planning A, 46 (2), 373-397.

[26] Potrafke, N. (2015). The evidence on globalisation. The World Economy, 38 (3), 509-552

[27] Persson, T., \& Tabellini, G. (1992). The Politics of 1992: Fiscal Policy and European Integration. Review of Economic Studies, 59 (4), 689-701.

[28] Quinn, D. (1997). The correlates of change in international financial regulation. The American Political Science Review, 91 (3), 531-551.

[29] Rodrik, D. (1997). Has Globalization Gone Too Far? Institute for International Economics: Washington, D.C. 
[30] Rodrik, D. (1998). Do more open economies have bigger governments? Journal of Political Economy, 106 (5), 997-1032.

[31] Rodrik, D. (2018). Populism and the economics of globalization. Journal of International Business Policy, 1 $(1-2), 12-33$

[32] Schulze, G.G., \& Ursprung, H.W. (1999). Globalisation of the Economy and the Nation State. The World Economy, 22 (3), 295-352.

[33] Solt, F. (2016). The standardized world income inequality database. Social Science Quarterly, 97 (5), 12671281.

[34] Swank, D. (2016). Taxing choices: international competition, domestic institutions and the transformation of corporate tax policy. Journal of European Public Policy, 23 (4), 571-603.

[35] Trefler, D. (1993). International Factor Price Differences: Leontief was Right! Journal of Political Economy, $101(6), 961-987$. 
Table 1

A Summary of the Descriptive Summary Statistics

\begin{tabular}{|c|c|c|c|c|c|c|c|}
\hline Variables & Definition & Data Source & Mean & Standard Deviation & Minimum & Maximum & Observations \\
\hline Top Marginal Income Tax Rate (TMITR) & Level, Ratio & Fraser Institute, Economic Freedom: Gwartney et al. (2017) & 35.91 & 16.90 & 0.000 & 100.0 & 2230 \\
\hline Top Marginal Income and Payroll Tax Rate (TMIPTR) & Level, Ratio & Fraser Institute, Economic Freedom: Gwartney et al. (2017) & 41.90 & 13.81 & 0.000 & 86.00 & 1810 \\
\hline Corporate Tax Rate (CTR) & Level, Ratio & KPMG's Corporate Tax Rate Table & 26.00 & 8.978 & 0.000 & 55.00 & 1182 \\
\hline Individual Income Tax Rate (IITR) & Level, Ratio & KPMG's Individual Income Tax Rate Table & 29.89 & 14.18 & 0.000 & 62.28 & 1122 \\
\hline Financial Openness (Chinn-Ito Index) (KOPEN_dj_CI) & Index from 0 to 1 & Chinn-Ito Index (Version 2017) Chinn and Ito (2006 and 2008) & 0.510 & 0.372 & 0.000 & 1.000 & 2909 \\
\hline Financial Liberalization (Economic Freedom) (KOPEN_dj_FI) & Index from 0 to 10 & Fraser Institute, Economic Freedom: Gwartney et al. (2017) & 6.625 & 2.136 & 0.000 & 10.00 & 2692 \\
\hline Real Trade Openness (Real Merchandise Exports plus Real Imports Relative to PPP GDP) (TLIB_df_Real) & Level, Ratio & PWT 9.0: Feenstra et al. (2015) & 55.40 & 45.81 & 0.130 & 609.1 & 3053 \\
\hline Nominal Trade Openness (Merchandise Exports plus Imports Relative to Nominal GDP) (TLIB_df_PWT) & Level, Ratio & PWT 9.0: Feenstra et al. (2015) & 80.60 & 46.38 & 5.300 & 439.6 & 3053 \\
\hline Nominal Trade openness (TLIB_df_WB) & Level, Ratio & World Bank, World Development Indicators & 81.58 & 46.29 & 0.167 & 441.6 & 2923 \\
\hline De Facto Measure of Trade Globalization Index (TLIB_df_KOF) & Index from 0 to 100 & KOF: Dreher (2006b) \& Gygli et al. (2018) & 52.31 & 20.66 & 2.628 & 98.61 & 3024 \\
\hline De Jure Measure of Trade Globalization Index (TLIB_dj_KOF) & Index from 0 to 100 & KOF: Dreher (2006b) \& Gygli et al. (2018) & 54.33 & 23.06 & 7.660 & 98.93 & 3024 \\
\hline De Facto Measure of Financial Globalization Index (KOPEN_df_KOF) & Index from 0 to 100 & KOF: Dreher (2006b) \& Gygli et al. (2018) & 56.34 & 21.53 & 3.598 & 99.39 & 3024 \\
\hline De Jure Measure of Financial Globalization Index (KOPEN_dj_KOF) & Index from 0 to 100 & KOF: Dreher (2006b) \& Gygli et al. (2018) & 48.17 & 24.57 & 1.000 & 91.28 & 3024 \\
\hline Per Capita GDP (PPPs, Constant 2005US\$) & Logarithmic form & PWT 9.0: Feenstra et al. (2015) & 8.822 & 1.250 & 5.046 & 12.42 & 3053 \\
\hline Population, Total & Logarithmic form & PWT 9.0: Feenstra et al. (2015) & 2.190 & 1.683 & -2.949 & 7.222 & 3053 \\
\hline Capital / Labor Ratio & Logarithmic form & PWT 9.0: Feenstra et al. (2015) & 10.72 & 1.455 & 5.690 & 14.27 & 2988 \\
\hline Level of Institutionalized Democracy & Index from 0 to 10 & Polity IV Annual Time Series: Marshall et al. (2017) & 5.338 & 3.979 & 0.000 & 10.00 & 2956 \\
\hline Civil Liberties Ratings (1 Representing the Most Free; 7 the Least Free) & Index from 1 to 7 & Freedom House, Freedom in the World Database & 3.471 & 1.788 & 1.000 & 7.000 & 3049 \\
\hline Institutional Quality (Executive Constraints Concept) & Index from 1 to 7 & Polity IV Annual Time Series: Marshall et al. (2017) & 4.812 & 2.133 & 1.000 & 7.000 & 2956 \\
\hline Gini Index of Income & Index from 0 to 100 & SWIID 6.0 (Version 2017): Solt (2016) & 38.50 & 8.392 & 18.29 & 60.88 & 2321 \\
\hline
\end{tabular}


Table 2

Correlation Matrix

\begin{tabular}{|c|c|c|c|c|c|c|c|c|c|c|c|c|c|}
\hline Regressors & TMITR & TMIPTR & CTR & IITR & TLIB_dj_KOF & TLIB_df_KOF & TLIB_df_WB & TLIB_df_PWT & TLIB_df_Real & KOPEN_dj_CI & KOPEN_dj_FI & KOPEN_dj_KOF & KOPEN_df_KOF \\
\hline TMITR & 1.000 & - & - & - & - & - & - & - & - & - & - & - & - \\
\hline TMIPTR & 0.801 & 1.000 & - & - & - & - & - & - & - & - & - & - & - \\
\hline CTR & 0.339 & 0.117 & 1.000 & - & - & - & - & - & - & - & - & - & - \\
\hline IITR & 0.957 & 0.748 & 0.270 & 1.000 & - & - & - & - & - & - & - & - & - \\
\hline TLIB_dj_KOF & -0.029 & 0.197 & -0.092 & 0.216 & 1.000 & - & - & - & - & - & - & - & - \\
\hline TLIB_df_KOF & -0.228 & -0.043 & -0.294 & -0.156 & 0.325 & 1.000 & - & - & - & - & - & - & - \\
\hline TLIB_df_WB & -0.232 & -0.150 & -0.247 & -0.152 & 0.290 & 0.778 & 1.000 & - & - & - & - & - & - \\
\hline TLIB_df_PWT & -0.215 & -0.136 & -0.243 & -0.136 & 0.298 & 0.774 & 0.961 & 1.000 & - & - & - & - & - \\
\hline TLIB_df_Real & -0.042 & 0.088 & -0.221 & 0.087 & 0.506 & 0.602 & 0.727 & 0.734 & 1.000 & - & - & - & - \\
\hline KOPEN_dj_CI & -0.122 & 0.089 & -0.068 & 0.117 & 0.645 & 0.226 & 0.226 & 0.217 & 0.377 & 1.000 & - & - & - \\
\hline KOPEN_dj_FI & -0.275 & -0.079 & -0.070 & -0.040 & 0.460 & 0.342 & 0.291 & 0.284 & 0.359 & 0.589 & 1.000 & - & - \\
\hline KOPEN_dj_KOF & 0.021 & 0.119 & -0.052 & 0.145 & 0.588 & 0.126 & 0.152 & 0.151 & 0.331 & 0.857 & 0.488 & 1.000 & - \\
\hline KOPEN_df_KOF & -0.114 & 0.144 & -0.215 & 0.205 & 0.599 & 0.618 & 0.548 & 0.554 & 0.620 & 0.507 & 0.490 & 0.427 & 1.000 \\
\hline
\end{tabular}

Note: TMITR: Top Marginal Income Tax Rate, TMIPTR: Top Marginal Income and Payroll Tax Rate, CTR: Corporate Tax Rate, IITR: Individual Income Tax

Rate, TLIB_dj_KOF: De Jure Measure of Trade Globalization Index, TLIB_df_KOF: De Facto Measure of Trade Globalization Index, TLIB _df_WB: Trade (WDI),

TLIB_df_PWT: Nominal Trade Openness, TLIB_df_Real: Real Trade Openness, KOPEN_dj_CI: Financial Openness (Chinn-Ito Index), KOPEN_dj_FI: Financial

Liberalization Index (EFW), KOPEN_dj_KOF: De Jure Measure of Financial Globalization Index, KOPEN_df_KOF: De Facto Measure of Financial Globalization

Index. 
Table 3

Baseline Regressions for the TMITR (All Countries, 1970-2015)

\begin{tabular}{|c|c|c|c|c|c|c|c|c|c|}
\hline Regressors & (I) & (II) & (III) & (IV) & $(\mathrm{V})$ & (VI) & (VII) & (VIII) & (IX) \\
\hline Constant Term & $1219^{* * *}(167.5)$ & $1422^{* * *}(177.8)$ & $1266^{* * *}(168.5)$ & $1371^{* * *}(173.5)$ & $1430^{* * *}(181.7)$ & $1092^{* * *}(169.6)$ & $943.7^{* * *}(148.8)$ & $1404^{* * *}(170.2)$ & $1330^{* * *}(244.9)$ \\
\hline Log Per Capita GDP & $-1.065(1.905)$ & $-1.163(1.844)$ & $-1.745(1.831)$ & $-1.425(1.864)$ & $-1.174(1.861)$ & $-1.096(1.760)$ & $-1.523(1.801)$ & $-0.896(1.807)$ & $-1.311(1.891)$ \\
\hline Log Population & $-1.101(4.516)$ & $-0.287(4.625)$ & $-2.273(4.514)$ & $-0.328(4.613)$ & $0.449(4.503)$ & $-5.720(4.778)$ & $-0.778(3.791)$ & $-0.256(5.015)$ & $-1.296(5.565)$ \\
\hline Time Trend & $-0.581^{* * *}(0.092)$ & $-0.687^{* * *}(0.098)$ & $-0.602^{* * *}(0.093)$ & $-0.660^{* * *}(0.095)$ & $-0.691^{* * *}(0.100)$ & $-0.512^{* * *}(0.093)$ & $-0.434^{* * *}(0.082)$ & $-0.673^{* * *}(0.094)$ & $-0.637^{* * *}(0.133)$ \\
\hline TLIB_dj_KOF & $-0.111^{* * *}(0.036)$ & - & - & - & - & - & - & - & - \\
\hline TLIB_df_KOF & - & $-0.053(0.048)$ & - & - & - & - & - & - & - \\
\hline TLIB_df_WB & - & - & $-0.013(0.019$ & - & - & - & - & - & - \\
\hline TLIB_df_PWT & - & - & - & $0.004(0.023)$ & - & - & - & - & - \\
\hline TLIB_df_Real & - & - & - & - & $0.019(0.019)$ & - & - & - & - \\
\hline KOPEN_dj_CI & - & - & - & - & - & $-9.387^{* * *}(1.517)$ & - & - & - \\
\hline KOPEN_dj_FI & - & - & - & - & - & - & $-2.909^{* * *}(0.351)$ & - & - \\
\hline KOPEN_dj_KOF & - & - & - & - & - & - & - & $-0.177^{* * *}(0.030)$ & - \\
\hline KOPEN_df_KOF & - & - & - & - & - & - & - & - & $-0.020(0.046)$ \\
\hline Country Fixed-Effects & Yes & Yes & Yes & Yes & Yes & Yes & Yes & Yes & Yes \\
\hline Observations & 2,223 & 2,223 & 2,196 & 2,227 & 2,227 & 2,206 & 2,227 & 2,223 & 2,203 \\
\hline Number of Countries & 149 & 149 & 149 & 149 & 149 & 149 & 149 & 149 & 148 \\
\hline Cluster-robust Hausman Test & $24.8[0.000]$ & $8.75[0.032]$ & $17.3[0.000]$ & $8.07[0.044]$ & $7.89[0.048]$ & $17.9[0.000]$ & $19.4[0.000]$ & $12.5[0.005]$ & $18.6[0.000]$ \\
\hline R-Squared (Within) & 0.478 & 0.472 & 0.472 & 0.471 & 0.472 & 0.517 & 0.535 & 0.495 & 0.476 \\
\hline
\end{tabular}

Notes: TLIB_dj_KOF: De Jure Measure of Trade Globalization Index, TLIB_df_KOF: De Facto Measure of Trade Globalization Index, TLIB _df_WB: Trade (WDI),

TLIB_df_PWT: Nominal Trade Openness, TLIB_df_Real: Real Trade Openness, KOPEN_dj_CI: Financial Openness (Chinn-Ito Index), KOPEN_dj_FI: Financial Liberalization Index (EFW), KOPEN_dj_KOF: De Jure Measure of Financial Globalization Index, KOPEN_df_KOF: De Facto Measure of Financial Globalization Index. The robust standard errors clustered at the country level are reported. The standard errors are in parentheses and the p-values are in brackets. ${ }^{* * *}$ indicates statistical significance at the $1 \%$ level. The Cluster-robust Hausman test confirms the validity of the fixed effect estimation. 
Table 4

Baseline Regressions for the TMIPTR (All Countries, 1970-2015)

\begin{tabular}{|c|c|c|c|c|c|c|c|c|c|}
\hline Regressors & (I) & (II) & (III) & (IV) & $(\mathrm{V})$ & (VI) & (VII) & (VIII) & (IX) \\
\hline Constant Term & $616.5^{* * *}(182.1)$ & $741.4^{* * *}(180.7)$ & $657.6^{* * *}(184.5)$ & $660.7^{* * *}(189.2)$ & $665.6^{* * *}(205.4)$ & $637.8^{* * *}(187.1)$ & $555.2^{* * *}(182.9)$ & $752.1^{* * *}(176.9)$ & $402.7^{* * *}(236.8)$ \\
\hline Log Per Capita GDP & $-1.159(1.749)$ & $-1.199(1.676)$ & $-1.418(1.703)$ & $-1.443(1.723)$ & $-1.486(1.740)$ & $-1.173(1.707)$ & $-0.968(1.618)$ & $-1.039(1.603)$ & $-1.865(1.760)$ \\
\hline Log Population & $6.237(4.937)$ & $6.483(5.028)$ & 5.717 (5.085) & $5.772(5.009)$ & $5.574(5.288)$ & $5.577(5.163)$ & $5.541(5.010)$ & $5.498(5.126)$ & $1.198(5.716)$ \\
\hline Time Trend & $-0.285^{* * *}(0.099)$ & $-0.351^{* * *}(0.098)$ & $-0.306^{* * *}(0.101)$ & $-0.308^{* * *}(0.103)$ & $-0.310^{* * *}(0.112)$ & $-0.296^{* * *}(0.112)$ & $-0.252^{* *}(0.101)$ & $-0.353^{* * *}(0.096)$ & $-0.168(0.128)$ \\
\hline TLIB_dj_KOF & $-0.089^{* * *}(0.031)$ & - & - & - & - & - & - & - & - \\
\hline TLIB_df_KOF & - & $0.017(0.035)$ & - & - & - & - & - & - & - \\
\hline TLIB_df_WB & - & - & $-0.024(0.015)$ & - & - & - & - & - & - \\
\hline TLIB_df_PWT & - & - & - & $-0.018(0.017)$ & - & - & - & - & - \\
\hline TLIB_df_Real & - & - & - & - & $-0.009(0.014)$ & - & - & - & - \\
\hline KOPEN_dj_CI & - & - & - & - & - & $-5.163^{* * *}(1.613)$ & - & - & - \\
\hline KOPEN_dj_FI & - & - & - & - & - & - & $-1.588^{* * *}(0.401)$ & - & - \\
\hline KOPEN_dj_KOF & - & - & - & - & - & - & - & $-0.107^{* * *}(0.031)$ & - \\
\hline KOPEN_df_KOF & - & - & - & - & - & - & - & - & $-0.125^{* * *}(0.040)$ \\
\hline Country Fixed-Effects & Yes & Yes & Yes & Yes & Yes & Yes & Yes & Yes & Yes \\
\hline Observations & 1,809 & 1,809 & 1,800 & 1,810 & 1,810 & 1,801 & 1,810 & 1,809 & 1,794 \\
\hline Number of Countries & 145 & 145 & 144 & 145 & 145 & 145 & 145 & 145 & 144 \\
\hline Cluster-robust Hausman Test & $21.1[0.000]$ & $17.5[0.000]$ & $19.6[0.000]$ & $16.2[0.000]$ & $15.8[0.000]$ & $23.1[0.000]$ & $21.7[0.000]$ & $22.4[0.005]$ & $19.3[0.000]$ \\
\hline R-Squared (Within) & 0.112 & 0.099 & 0.102 & 0.101 & 0.099 & 0.118 & 0.134 & 0.124 & 0.121 \\
\hline
\end{tabular}

Notes: TLIB_dj_KOF: De Jure Measure of Trade Globalization Index, TLIB_df_KOF: De Facto Measure of Trade Globalization Index, TLIB_df_WB: Trade (WDI), TLIB_df_PWT: Nominal Trade Openness, TLIB_df_Real: Real Trade Openness, KOPEN_dj_CI: Financial Openness (Chinn-Ito Index), KOPEN_dj_FI: Financial Liberalization Index (EFW), KOPEN_dj_KOF: De Jure Measure of Financial Globalization Index, KOPEN_df_KOF: De Facto Measure of Financial Globalization Index. The robust standard errors clustered at the country level are reported. The standard errors are in parentheses and the p-values are in brackets. ${ }^{* * *}{ }^{* *}$, and ${ }^{*}$ indicate statistical significance at the $1 \%, 5 \%$, and $10 \%$ levels, respectively. The Cluster-robust Hausman test confirms the validity of the fixed effect estimation. 
Table 5

Baseline Regressions for the TMITR (All Countries, 2003-2015)

\begin{tabular}{|c|c|c|c|c|c|c|c|c|c|}
\hline Regressors & (I) & (II) & (III) & (IV) & $(\mathrm{V})$ & (VI) & (VII) & (VII) & (IX) \\
\hline Constant Term & $393.3(248.6)$ & $471.5^{*}(247.3)$ & $365.7(247.3)$ & $369.2(242.7)$ & $359.9(250.8)$ & $434.1^{*}(253.2)$ & $365.1(237.6)$ & $499.2^{*}(261.3)$ & $253.9(262.3)$ \\
\hline Log Per Capita GDP & $-2.967^{*}(1.582)$ & $-2.756^{*}(1.576)$ & $-3.415^{* *}(1.621)$ & $-3.369^{* *}(1.595)$ & $-3.430^{* *}(1.681)$ & $-3.022^{*}(1.648)$ & $-2.695^{*}(1.582)$ & $-3.004^{*}(1.595)$ & $-3.782^{* *}(1.697)$ \\
\hline Log Population & $3.198(5.108)$ & $4.091(5.166)$ & $3.538(5.210)$ & $3.429(5.050)$ & $3.271(5.042)$ & $3.651(5.200)$ & $1.659(4.898)$ & $3.728(5.132)$ & $1.604(5.066)$ \\
\hline Time Trend & $-0.168(0.130)$ & $-0.212(0.130)$ & $-0.154(0.129)$ & $-0.156(0.127)$ & $-0.151(0.132)$ & $-0.189(0.133)$ & $-0.150(0.124)$ & $-0.222(0.136)$ & $-0.090(0.138)$ \\
\hline TLIB_dj_KOF & $-0.049(0.038)$ & - & - & - & - & - & - & - & - \\
\hline TLIB_df_KOF & - & $0.059^{*}(0.031)$ & - & - & - & - & - & - & - \\
\hline TLIB_df_WB & - & - & $-0.010(0.016)$ & - & - & - & - & - & - \\
\hline TLIB_df_PWT & - & - & - & $-0.011(0.017)$ & - & - & - & - & - \\
\hline TLIB_df_Real & - & - & - & - & $-0.012(0.015)$ & - & - & - & - \\
\hline KOPEN_dj_CI & - & - & - & - & - & $-5.461^{* * *}(2.001)$ & - & - & - \\
\hline KOPEN_dj_FI & - & - & - & - & - & - & $-1.507^{* * *}(0.481)$ & - & - \\
\hline KOPEN_dj_KOF & - & - & - & - & - & - & - & $-0.089^{* * *}(0.034)$ & - \\
\hline KOPEN_df_KOF & - & - & - & - & - & - & - & - & $-0.135^{* * *}(0.038)$ \\
\hline Country Fixed-Effects & Yes & Yes & Yes & Yes & Yes & Yes & Yes & Yes & Yes \\
\hline Observations & 1,512 & 1,512 & 1,512 & 1,512 & 1,512 & 1,510 & 1,512 & 1,512 & 1,510 \\
\hline Number of Countries & 149 & 149 & 149 & 149 & 149 & 149 & 149 & 149 & 148 \\
\hline Cluster-robust Hausman Test & $37.2[0.000]$ & $17.3[0.000]$ & $34.1[0.000]$ & $16.4[0.000]$ & $15.8[0.003]$ & $27.5[0.000]$ & $25.3[0.000]$ & $24.6[0.000]$ & $26.8[0.000]$ \\
\hline R-Squared (Within) & 0.052 & 0.053 & 0.052 & 0.049 & 0.049 & 0.059 & 0.069 & 0.060 & 0.075 \\
\hline
\end{tabular}
TLIB_df_PWT: Nominal Trade Openness, TLIB_df_Real: Real Trade Openness, KOPEN_dj_CI: Financial Openness (Chinn-Ito Index), KOPEN_dj_FI: Financial Liberalization Index (EFW), KOPEN_dj_KOF: De Jure Measure of Financial Globalization Index, KOPEN_df_KOF: De Facto Measure of Financial Globalization Index. The robust standard errors clustered at the country level are reported. The standard errors are in parentheses and the p-values are in brackets. ${ }^{* * *}{ }^{* *}$, and ${ }^{*}$ indicate statistical significance at the $1 \%, 5 \%$, and $10 \%$ levels, respectively. The Cluster-robust Hausman test confirms the validity of the fixed effect estimation. 
Table 6

Baseline Regressions for the TMIPTR (All Countries, 2003-2015)

\begin{tabular}{|c|c|c|c|c|c|c|c|c|c|}
\hline Regressors & (I) & (II) & (III) & (IV) & (V) & (VI) & (VII) & (VIII) & (IX) \\
\hline Constant Term & $175.6(303.5)$ & $215.1(310.2)$ & $109.7(321.2)$ & $94.64(319.1)$ & $44.26(312.3)$ & $286.4^{*}(315.6)$ & $28.33(343.5)$ & $205.9(316.7)$ & $153.6(307.7)$ \\
\hline Log Per Capita GDP & $-4.326^{* *}(2.166)$ & $-4.509^{* *}(2.202)$ & $-5.043^{* *}(2.307)$ & $-5.087^{* *}(2.321)$ & $-5.336^{* *}(2.208)$ & $-4.374^{*}(2.223)$ & $-5.126^{* *}(2.368)$ & $-4.595^{* *}(2.317)$ & $-4.043^{*}(2.218)$ \\
\hline Log Population & $8.617(6.621)$ & $9.448(6.635)$ & $8.723(6.667)$ & $8.466(6.551)$ & $7.901(6.679)$ & $8.657(6.661)$ & $6.519(6.802)$ & $8.917(6.718)$ & $6.899(6.601)$ \\
\hline Time Trend & $-0.075^{* *}(0.035)$ & $-0.078(0.165)$ & $-0.020(0.172)$ & $-0.012(0.171)$ & $-0.014(0.167)$ & $-0.110(0.168)$ & $-0.026(0.184)$ & $-0.070(0.170)$ & $-0.040(0.165)$ \\
\hline TLIB_dj_KOF & $-0.055(0.162)$ & - & - & - & - & - & - & - & - \\
\hline TLIB_df_KOF & - & $0.022(0.042)$ & - & - & - & - & - & - & - \\
\hline TLIB_df_WB & - & - & $-0.025(0.018)$ & - & - & - & - & - & - \\
\hline TLIB_df_PWT & - & - & - & $-0.028(0.018)$ & - & - & - & - & - \\
\hline TLIB_df_Real & - & - & - & - & $-0.037^{* *}(0.016)$ & - & - & - & - \\
\hline KOPEN_dj_KOF & - & - & - & - & - & $-0.098^{* *}(0.045)$ & - & - & - \\
\hline KOPEN_df_KOF & - & - & - & - & - & - & $-0.131^{* * *}(0.047)$ & - & - \\
\hline KOPEN_dj_CI & - & - & - & - & - & - & - & $-5.828^{* *}(2.425)$ & - \\
\hline KOPEN_dj_FI & - & - & - & - & - & - & - & - & $-1.465^{* * *}(0.473)$ \\
\hline Country Fixed-Effects & Yes & Yes & Yes & Yes & Yes & Yes & Yes & Yes & Yes \\
\hline Observations & 1,400 & 1,400 & 1,392 & 1,400 & 1,400 & 1,400 & 1,388 & 1,398 & 1,400 \\
\hline Number of Countries & 145 & 145 & 144 & 145 & 145 & 145 & 144 & 145 & 145 \\
\hline Cluster-robust Hausman Test & $34.1[0.000]$ & $19.6[0.000]$ & $30.9[0.000]$ & $19.1[0.000]$ & $18.3[0.000]$ & $22.5[0.000]$ & $28.3[0.000]$ & $25.6[0.000]$ & $28.0[0.000]$ \\
\hline R-Squared (Within) & 0.048 & 0.040 & 0.043 & 0.044 & 0.048 & 0.054 & 0.065 & 0.054 & 0.060 \\
\hline
\end{tabular}

TLIB_df_PWT: Nominal Trade Openness, TLIB_df_Real: Real Trade Openness, KOPEN_dj_CI: Financial Openness (Chinn-Ito Index), KOPEN_dj_FI: Financial Liberalization Index (EFW), KOPEN_dj_KOF: De Jure Measure of Financial Globalization Index, KOPEN_df_KOF: De Facto Measure of Financial Globalization Index. The robust standard errors clustered at the country level are reported. The standard errors are in parentheses and the p-values are in brackets. $* * * * *$ and ${ }^{*}$ indicate statistical significance at the $1 \%, 5 \%$, and $10 \%$ levels, respectively. The Cluster-robust Hausman test confirms the validity of the fixed effect estimation. 
Table 7

Baseline Regressions for the IITR (All Countries, 2003-2015)

\begin{tabular}{|c|c|c|c|c|c|c|c|c|c|}
\hline Regressors & (I) & (II) & (III) & (IV) & $(\mathrm{V})$ & (VI) & (VII) & (VIII) & (IX) \\
\hline Constant Term & $204.9(235.9)$ & $261.7(223.4)$ & $207.6(219.8)$ & $202.7(195.2)$ & $141.8(215.7)$ & $303.4(225.1)$ & $69.88(240.2)$ & $199.6(232.3)$ & $203.3(238.7)$ \\
\hline Log Per Capita GDP & $-3.455(2.301)$ & $-3.413(2.143)$ & $-3.825^{*}(2.223)$ & $-3.756^{*}(2.119)$ & $-3.904^{*}(2.248)$ & $-3.663^{*}(2.182)$ & $-4.195^{*}(2.251)$ & $-4.048^{*}(2.264)$ & $-3.143(2.343)$ \\
\hline Log Population & 3.585 (3.164) & 4.208 (3.299) & $3.936(3.235)$ & $3.530(3.071)$ & $2.954(2.962)$ & $4.184(3.137)$ & $2.941(3.004)$ & $3.601(3.203)$ & $3.976(3.901)$ \\
\hline Time Trend & $-0.073(0.124)$ & $-0.106(0.117)$ & $-0.075(0.115)$ & $-0.072(0.102)$ & $-0.039(0.114)$ & $-0.121(0.118)$ & $-0.001(0.126)$ & $-0.067(0.123)$ & $-0.071(0.127)$ \\
\hline TLIB_dj_KOF & $-0.050(0.049)$ & - & - & - & - & - & - & - & - \\
\hline TLIB_df_KOF & - & $0.060(0.051)$ & - & - & - & - & - & - & - \\
\hline TLIB_df_WB & - & - & $-0.003(0.017)$ & - & - & - & - & - & - \\
\hline TLIB_df_PWT & - & - & - & $-0.009(0.019)$ & - & - & - & - & - \\
\hline TLIB_df_Real & - & - & - & - & $-0.035^{* *}(0.016)$ & - & - & - & - \\
\hline KOPEN_dj_KOF & - & - & - & - & - & $-0.098^{* *}(0.047)$ & - & - & - \\
\hline KOPEN_df_KOF & - & - & - & - & - & - & $-0.123^{* * *}(0.045)$ & - & - \\
\hline KOPEN_dj_CI & - & - & - & - & - & - & - & $-5.788^{* *}(2.764)$ & - \\
\hline KOPEN_dj_FI & - & - & - & - & - & - & - & - & $-1.494^{* * *}(0.442)$ \\
\hline Country Fixed-Effects & Yes & Yes & Yes & Yes & Yes & Yes & Yes & Yes & Yes \\
\hline Observations & 1,121 & 1,121 & 1,113 & 1,122 & 1,122 & 1,121 & 1,109 & 1,119 & 1,094 \\
\hline Number of Countries & 113 & 113 & 113 & 113 & 113 & 113 & 112 & 112 & 113 \\
\hline Cluster-robust Hausman Test & $22.7[0.000]$ & $20.1[0.000]$ & $24.5[0.000]$ & $21.6[0.000]$ & $20.3[0.000]$ & $22.2[0.000]$ & $20.9[0.000]$ & $21.4[0.000]$ & $21.8[0.000]$ \\
\hline R-Squared (Within) & 0.048 & 0.048 & 0.044 & 0.045 & 0.054 & 0.065 & 0.072 & 0.066 & 0.073 \\
\hline
\end{tabular}

Notes: TLIB_dj_KOF: De Jure Measure of Trade Globalization Index, TLIB_df_KOF: De Facto Measure of Trade Globalization Index, TLIB _df_WB: Trade (WDI), TLIB_df_PWT: Nominal Trade Openness, TLIB_df_Real: Real Trade Openness, KOPEN_dj_CI: Financial Openness (Chinn-Ito Index), KOPEN_dj_FI: Financial Liberalization Index (EFW), KOPEN_dj_KOF: De Jure Measure of Financial Globalization Index, KOPEN_df_KOF: De Facto Measure of Financial Globalization Index. The robust standard errors clustered at the country level are reported. The standard errors are in parentheses and the p-values are in brackets. ${ }^{* * *}$, **, and ${ }^{*}$ indicate statistical significance at the $1 \%, 5 \%$, and $10 \%$ levels, respectively. The Cluster-robust Hausman test confirms the validity of the fixed effect estimation. 
Table 8

Baseline Regressions for the CTR (All Countries, 2003-2015)

\begin{tabular}{|c|c|c|c|c|c|c|c|c|c|}
\hline Regressors & (I) & (II) & (III) & (IV) & (V) & (VI) & (VII) & (VIII) & (IX) \\
\hline Constant Term & $855.7^{* * *}(167.1)$ & $823.8^{* * *}(170.7)$ & $856.3^{* * *}(173.5)$ & $854.8^{* * *}(170.8)$ & $833.1^{* * *}(172.1)$ & $924.1^{* * *}(167.6)$ & $794.1^{* * *}(167.9)$ & $857.1^{* * *}(166.5)$ & $891.1^{* * *}(151.7)$ \\
\hline Log Per Capita GDP & $-0.064(1.859)$ & $-0.303(1.893)$ & $-0.040(1.846)$ & $-0.052(1.825)$ & $-0.144(1.887)$ & $-0.020(1.886)$ & $-0.081(1.935)$ & $-0.166(1.876)$ & $-0.434(1.701)$ \\
\hline Log Population & $-10.04(7.804)$ & $-10.22(7.771)$ & $-10.21(7.759)$ & $-10.07(7.899)$ & $-10.20(7.875)$ & $-9.865(7.882)$ & $-10.96(7.973)$ & -10.18 (7.799) & $-6.861(8.746)$ \\
\hline Time Trend & $-0.400^{* * *}(0.089)$ & $-0.381^{* * *}(0.091)$ & $-0.400^{* * *}(0.092)$ & $-0.399^{* * *}(0.091)$ & $-0.387^{* * *}(0.092)$ & $-0.432^{* * *}(0.089)$ & $-0.364^{* * *}(0.089)$ & $-0.398^{* * *}(0.089)$ & $-0.421^{* * *}(0.081)$ \\
\hline TLIB_dj_KOF & $0.003(0.034)$ & - & - & - & - & - & - & - & - \\
\hline TLIB_df_KOF & - & $-0.036(0.038)$ & - & - & - & - & - & - & - \\
\hline TLIB_df_WB & - & - & $0.009(0.014)$ & - & - & - & - & - & - \\
\hline TLIB_df_PWT & - & - & - & $-0.001(0.016)$ & - & - & - & - & - \\
\hline TLIB_df_Real & - & - & - & - & $-0.006(0.011)$ & - & - & - & - \\
\hline KOPEN_dj_KOF & - & - & - & - & - & $-0.074^{* * *}(0.025)$ & - & - & - \\
\hline KOPEN_df_KOF & - & - & - & - & - & - & $-0.090^{* *}(0.037)$ & - & - \\
\hline KOPEN_dj_CI & - & - & - & - & - & - & - & $-3.268^{* *}(1.534)$ & - \\
\hline KOPEN_dj_FI & - & - & - & - & - & - & - & - & $-0.978^{* * *}(0.311)$ \\
\hline Country Fixed-Effects & Yes & Yes & Yes & Yes & Yes & Yes & Yes & Yes & Yes \\
\hline Observations & 1,182 & 1,182 & 1,174 & 1,182 & 1,182 & 1,182 & 1,170 & 1,182 & 1,155 \\
\hline Number of Countries & 109 & 109 & 109 & 109 & 109 & 109 & 108 & 109 & 109 \\
\hline Cluster-robust Hausman Test & $26.7[0.000]$ & $22.1[0.000]$ & $24.3[0.000]$ & $24.5[0.000]$ & $21.6[0.000]$ & $23.4[0.000]$ & $25.8[0.000]$ & $22.2[0.000]$ & $24.9[0.000]$ \\
\hline R-Squared (Within) & 0.267 & 0.270 & 0.265 & 0.267 & 0.268 & 0.279 & 0.286 & 0.274 & 0.257 \\
\hline
\end{tabular}

Notes: TLIB_dj_KOF: De Jure Measure of Trade Globalization Index, TLIB_df_KOF: De Facto Measure of Trade Globalization Index, TLIB_df_WB: Trade (WDI), TLIB_df_PWT: Nominal Trade Openness, TLIB_df_Real: Real Trade Openness, KOPEN_dj_CI: Financial Openness (Chinn-Ito Index), KOPEN_dj_FI: Financial Liberalization Index (EFW), KOPEN_dj_KOF: De Jure Measure of Financial Globalization Index, KOPEN_df_KOF: De Facto Measure of Financial Globalization Index. The robust standard errors clustered at the country level are reported. The standard errors are in parentheses and the p-values are in brackets. ${ }^{* * *}{ }^{* *}$, and ${ }^{*}$ indicate statistical significance at the $1 \%, 5 \%$, and $10 \%$ levels, respectively. The Cluster-robust Hausman test confirms the validity of the fixed effect estimation. 
Table 9

Cross-Section Estimations for the Interaction Terms (All Countries, Period Average) (Trade Globalization Measure)

\begin{tabular}{|c|c|c|c|c|c|c|c|c|}
\hline Regressors & $\begin{array}{c}\text { TMITR } \\
\text { (I) }\end{array}$ & $\begin{array}{c}\text { TMITR } \\
\text { (II) } \\
\end{array}$ & $\begin{array}{c}\text { TMIPTR } \\
\text { (III) }\end{array}$ & $\begin{array}{c}\text { TMIPTR } \\
\text { (IV) }\end{array}$ & $\begin{array}{l}\text { CTR } \\
(\mathrm{V}) \\
\end{array}$ & $\begin{array}{l}\text { CTR } \\
\text { (VI) } \\
\end{array}$ & $\begin{array}{l}\text { IITR } \\
\text { (VII) } \\
\end{array}$ & $\begin{array}{l}\text { IITR } \\
\text { (VIII) } \\
\end{array}$ \\
\hline Constant Term & $125.8^{* * *}(21.79)$ & $43.87^{*}(22.78)$ & $104.1^{* * *}(21.44)$ & $88.19^{* * *}(19.01)$ & $59.85^{* *}(23.05)$ & $-14.94(21.52)$ & $116.1(32.86)$ & $9.328(34.32)$ \\
\hline Log Per Capita GDP & $-5.290(3.517)$ & $0.024(1.699)$ & $-9.420^{* *}(4.012)$ & $-0.059(1.649)$ & $0.829(2.597)$ & $0.393(1.413)$ & $-7.189 *(4.153)$ & $0.412(1.881)$ \\
\hline Log Population & $1.855^{* * *}(0.548)$ & $1.564^{* * *}(0.542)$ & $1.642^{* * *}(0.573)$ & $0.975^{*}(0.535)$ & $1.911^{* * *}(0.493)$ & $2.032^{* * *}(0.519)$ & $2.193^{* * *}(0.662)$ & $1.982^{* * *}(0.626)$ \\
\hline Log Capital-Labor Ratio & $-5.032(3.496)$ & - & $0.651(3.750)$ & - & $-3.877(3.075)$ & - & $-3.288(4.872)$ & - \\
\hline Gini Market Index & - & $-41.70(46.75)$ & - & $-125.5^{* * *}(39.50)$ & - & $72.45^{*}(39.80)$ & - & $2.592(63.87)$ \\
\hline TLIB_dj_KOF & $-1.964^{* * *}(0.463)$ & $-0.408(0.420)$ & $-1.308^{* * *}(0.448)$ & $-0.897^{* *}(0.366)$ & $-0.733^{*}(0.417)$ & $0.434(0.353)$ & $-1.711^{* * *}(0.584)$ & $0.023(0.533)$ \\
\hline TLIB_dj_KOF ${ }^{*}$ Log Capital-Labor Ratio & $0.178^{* * *}(0.039)$ & - & $0.129^{* * *}(0.038)$ & - & $0.059^{*}(0.035)$ & - & $0.163^{* * *}(0.050)$ & - \\
\hline TLIB_dj_KOF * Gini Market Index & - & $1.008(0.844)$ & - & $2.244^{* * *}(0.709)$ & - & $-0.974(0.702)$ & - & $0.318(1.089)$ \\
\hline Observations & 149 & 145 & 145 & 141 & 109 & 105 & 113 & 109 \\
\hline R-Squared & 0.199 & 0.073 & 0.188 & 0.126 & 0.200 & 0.200 & 0.219 & 0.161 \\
\hline
\end{tabular}

Notes: TMITR: Top Marginal Income Tax Rate, TMIPTR: Top Marginal Income and Payroll Tax Rate, CTR: Corporate Tax Rate, IITR: Individual Income Tax Rate, TLIB_dj_KOF: De Jure Measure of Trade Globalization Index. The robust standard errors are in parentheses. ${ }^{* *},{ }^{* *}$, and ${ }^{*}$ indicate statistical significance at the $1 \%, 5 \%$, and $10 \%$ levels, respectively. 
Table 10

Cross-Section Estimations for the Interaction Terms (All Countries, Period Average) (Financial Openness Measure)

\begin{tabular}{|c|c|c|c|c|c|c|c|c|}
\hline Regressors & $\begin{array}{l}\text { TMITR } \\
\text { (I) }\end{array}$ & $\begin{array}{c}\text { TMITR } \\
\text { (II) }\end{array}$ & $\begin{array}{l}\text { TMIPTR } \\
\text { (III) }\end{array}$ & $\begin{array}{l}\text { TMIPTR } \\
\text { (IV) }\end{array}$ & $\begin{array}{l}\text { CTR } \\
\text { (V) }\end{array}$ & $\begin{array}{l}\text { CTR } \\
\text { (VI) }\end{array}$ & $\begin{array}{l}\text { IITR } \\
\text { (VII) }\end{array}$ & $\begin{array}{l}\text { IITR } \\
\text { (VIII) } \\
\end{array}$ \\
\hline Constant Term & $73.10^{* * *}(13.51)$ & $19.01(12.85)$ & $65.92^{* * *}(12.41)$ & $40.86^{* * *}(11.61)$ & $39.55^{* * *}(11.31)$ & $9.930(10.65)$ & $42.38^{* *}(18.44)$ & $-2.262(17.05)$ \\
\hline Log Per Capita GDP & $-6.121^{*}(3.144)$ & $1.144(1.081)$ & $-9.135^{* *}(3.744)$ & $1.534(1.098)$ & $0.581(2.669)$ & $0.077(0.871)$ & $-7.328^{*}(3.821)$ & $2.186(1.409)$ \\
\hline Log Population & $1.756^{* * *}(0.577)$ & $1.628^{* * *}(0.557)$ & $1.578^{* *}(0.615)$ & $1.094^{*}(0.582)$ & $1.912^{* * *}(0.502)$ & $1.922^{* * *}(0.495)$ & $2.345^{* * *}(0.709)$ & $2.021^{* * *}(0.662)$ \\
\hline Log Capital-Labor Ratio & $0.685(2.765)$ & - & $4.521(3.110)$ & - & $-2.113(2.383)$ & - & 3.937 (3.459) & - \\
\hline Gini Market Index & - & $0.035(23.06)$ & - & $-37.43^{* *}(17.03)$ & - & $23.22(15.19)$ & - & $10.89(24.79)$ \\
\hline KOPEN_dj_CI & $-109.2^{* * *}(22.90)$ & $-18.96(18.40)$ & $-88.94^{* * *}(20.79)$ & $-40.17^{*}(20.86)$ & $-28.07(18.81)$ & $8.634(12.48)$ & $-74.93^{* *}(28.53)$ & $-7.389(19.34)$ \\
\hline KOPEN_dj_CI ${ }^{*}$ Log Capital-Labor Ratio & $9.747^{* * *}(2.135)$ & - & $8.174^{* * *}(1.952)$ & - & $2.439(1.739)$ & - & $7.037^{* * *}(2.591)$ & - \\
\hline KOPEN_dj_CI * Gini Market Index & - & $36.31(37.78)$ & - & $88.36^{* *}(44.74)$ & - & $-18.55(27.01)$ & - & $-2.262(17.05)$ \\
\hline Observations & 149 & 145 & 145 & 141 & 109 & 105 & 113 & 109 \\
\hline R-Squared & 0.172 & 0.066 & 0.167 & 0.082 & 0.191 & 0.187 & 0.168 & 0.134 \\
\hline
\end{tabular}

Notes: TMITR: Top Marginal Income Tax Rate, TMIPTR: Top Marginal Income and Payroll Tax Rate, CTR: Corporate Tax Rate, IITR: Individual Income Tax Rate, KOPEN_dj_CI: Financial Openness (Chinn-Ito Index). The robust standard errors are in parentheses. ${ }^{* *},{ }^{* *}$, and ${ }^{*}$ indicate statistical significance at the $1 \%$, $5 \%$, and $10 \%$ levels, respectively. 
Table 11

Baseline Regressions (The Low- and the Lower-Middle Income Economies)

\begin{tabular}{|c|c|c|c|c|c|c|c|c|}
\hline Regressors & $\begin{array}{c}\text { TMITR } \\
\text { (I) } \\
\end{array}$ & $\begin{array}{c}\text { TMITR } \\
\text { (II) }\end{array}$ & $\begin{array}{l}\text { TMIPTR } \\
\text { (III) }\end{array}$ & $\begin{array}{l}\text { TMIPTR } \\
\text { (IV) } \\
\end{array}$ & $\begin{array}{l}\text { CTR } \\
(\mathrm{V}) \\
\end{array}$ & $\begin{array}{l}\text { CTR } \\
(\mathrm{VI}) \\
\end{array}$ & $\begin{array}{l}\text { IITR } \\
\text { (VII) } \\
\end{array}$ & $\begin{array}{l}\text { IITR } \\
\text { (VIII) }\end{array}$ \\
\hline Constant Term & $1218^{* * *}(408.2)$ & $1288^{* * *}(436.6)$ & $1413^{* * *}(404.5)$ & $1509^{* * *}(405.1)$ & $953.6^{* *}(440.7)$ & $1026^{* * *}(429.9)$ & $-27.15(426.9)$ & $6.718(435.2)$ \\
\hline Log Per Capita GDP & $-0.520(2.361)$ & $-0.506(2.418)$ & $0.709(2.106)$ & $0.771(2.207)$ & $0.278(2.545)$ & $-0.429(2.569)$ & $-1.017(2.711)$ & $-12.68(10.13)$ \\
\hline Log Population & $-12.69^{*}(7.446)$ & $-8.315(8.239)$ & $10.41(9.443)$ & $13.48(9.624)$ & $2.193(10.41)$ & 3.444 (10.69) & $-13.25(10.59)$ & $-2.798(1.835)$ \\
\hline Time Trend & $-0.570^{* *}(0.218)$ & $-0.621^{* *}(0.234)$ & $-0.703^{* * *}(0.219)$ & $-0.755^{* * *}(0.221)$ & $-0.464^{*}(0.233)$ & $-0.499^{* *}(0.228)$ & $0.054(0.228)$ & $0.038(0.231)$ \\
\hline TLIB_dj_KOF & $0.035(0.063)$ & - & $0.005(0.062)$ & - & $-0.048(0.074)$ & - & $-0.029(0.057)$ & - \\
\hline KOPEN_dj_CI & - & $-11.90^{* * *}(2.407)$ & - & $-5.871^{* *}(2.913)$ & - & $-5.152^{* *}(1.925)$ & - & $-2.798(1.835)$ \\
\hline Country Fixed-Effects & Yes & Yes & Yes & Yes & Yes & Yes & Yes & Yes \\
\hline Observations & 784 & 784 & 593 & 592 & 293 & 293 & 290 & 288 \\
\hline Number of Countries & 66 & 66 & 63 & 63 & 31 & 31 & 37 & 36 \\
\hline Cluster-robust Hausman Test & $39.1[0.000]$ & $8.51[0.036]$ & $12.7[0.021]$ & $28.5[0.000]$ & $22.4[0.004]$ & $24.5[0.000]$ & $21.3[0.005]$ & $54.2[0.000]$ \\
\hline R-Squared (Within) & 0.501 & 0.542 & 0.191 & 0.203 & 0.219 & 0.237 & 0.067 & 0.071 \\
\hline
\end{tabular}

Notes: TMITR: Top Marginal Income Tax Rate, TMIPTR: Top Marginal Income and Payroll Tax Rate, CTR: Corporate Tax Rate, IITR: Individual Income Tax Rate, TLIB_dj_KOF: De Jure Measure of Trade Globalization Index, KOPEN_dj_KOF: De Jure Measure of Financial Globalization Index. The robust standard errors clustered at the country level are reported. The standard errors are in parentheses and the p-values are in brackets. ${ }^{* *},{ }^{* *}$, and ${ }^{*}$ indicate statistical significance at the $1 \%, 5 \%$, and 10\% levels, respectively. The Cluster-robust Hausman test confirms the validity of the fixed effect estimation. 
Table 12

Baseline Regressions (The Upper-Middle- and the High-Income Economies)

\begin{tabular}{|c|c|c|c|c|c|c|c|c|}
\hline Regressors & $\begin{array}{l}\text { TMITR } \\
\text { (I) }\end{array}$ & $\begin{array}{l}\text { TMITR } \\
\text { (II) }\end{array}$ & $\begin{array}{l}\text { TMIPTR } \\
\text { (III) }\end{array}$ & $\begin{array}{c}\text { TMIPTR } \\
\text { (IV) }\end{array}$ & $\begin{array}{l}\text { CTR } \\
(\mathrm{V})\end{array}$ & $\begin{array}{l}\text { CTR } \\
(\mathrm{VI})\end{array}$ & $\begin{array}{l}\text { IITR } \\
\text { (VII) }\end{array}$ & $\begin{array}{c}\text { IITR } \\
\text { (VIII) }\end{array}$ \\
\hline Constant Term & $1039^{* * *}(192.2)$ & $993.1^{* * *}(181.6)$ & $462.7^{* * *}(196.1)$ & $474.9^{* *}(212.6)$ & $812.1^{* * *}(177.8)$ & $811.3^{* * *}(99.21)$ & $168.6^{* * *}(264.9)$ & $168.1^{* * *}(25.86)$ \\
\hline Log Per Capita GDP & $-3.959(2.835)$ & $-4.234^{*}(2.463)$ & $-3.071(2.549)$ & $-2.931(2.498)$ & $-1.671(2.272)$ & $-1.636(1.043)$ & -4.735 (3.549) & $-4.916(3.388)$ \\
\hline Log Population & $3.612(3.758)$ & $0.302(4.287)$ & $12.34^{* *}(5.719)$ & $11.97^{* *}(5.738)$ & $-12.05(8.198)$ & $-12.18^{* * *}(1.653)$ & $5.325(3.393)$ & $5.468(3.483)$ \\
\hline Time Trend & $-0.480^{* * *}(0.110)$ & $-0.454^{* * *}(0.103)$ & $-0.203^{*}(0.109)$ & $-0.211^{*}(0.117)$ & $-0.371^{* * *}(0.095)$ & $-0.368^{* * *}(0.053)$ & $-0.048(0.142)$ & $-0.047(0.138)$ \\
\hline TLIB_dj_KOF & $-0.158^{* * *}(0.041)$ & - & $-0.109^{* * *}(0.037)$ & - & $0.010(0.039)$ & - & $-0.068(0.058)$ & - \\
\hline KOPEN_dj_CI & - & $-8.133^{* * *}(1.767)$ & - & $-5.918^{* * *}(1.887)$ & - & $-2.410(1.860)$ & - & $-7.042^{* *}(3.528)$ \\
\hline Country Fixed-Effects & Yes & Yes & Yes & Yes & Yes & Yes & Yes & Yes \\
\hline Observations & 1,439 & 1,422 & 1,216 & 1,209 & 889 & 889 & 831 & 831 \\
\hline Number of Countries & 83 & 83 & 82 & 82 & 78 & 78 & 76 & 76 \\
\hline Cluster-robust Hausman Test & $63.2[0.000]$ & $8.29[0.040]$ & $13.5[0.015]$ & $10.3[0.012]$ & $6.92[0.074]$ & $6.53[0.088]$ & $7.14[0.061]$ & $7.21[0.059]$ \\
\hline R-Squared (Within) & 0.501 & 0.527 & 0.114 & 0.121 & 0.294 & 0.297 & 0.062 & 0.084 \\
\hline
\end{tabular}

Notes: TMITR: Top Marginal Income Tax Rate, TMIPTR: Top Marginal Income and Payroll Tax Rate, CTR: Corporate Tax Rate, IITR: Individual Income Tax Rate, TLIB_dj_KOF: De Jure Measure of Trade Globalization Index, KOPEN_dj_KOF: De Jure Measure of Financial Globalization Index. The robust standard errors clustered at the country level are reported. The standard errors are in parentheses and the p-values are in brackets. ${ }^{* *}, * *$ and $*$ indicate statistical significance at the $1 \%, 5 \%$, and $10 \%$ levels, respectively. The Cluster-robust Hausman test confirms the validity of the fixed effect estimation. 
Table 13

Baseline Regressions (The Non-OECD Countries)

\begin{tabular}{|c|c|c|c|c|c|c|c|c|}
\hline Regressors & $\begin{array}{l}\text { TMITR } \\
\text { (I) }\end{array}$ & $\begin{array}{c}\text { TMITR } \\
\text { (II) }\end{array}$ & $\begin{array}{c}\text { TMIPTR } \\
\text { (III) }\end{array}$ & $\begin{array}{l}\text { TMIPTR } \\
\text { (IV) }\end{array}$ & $\begin{array}{l}\text { CTR } \\
(\mathrm{V}) \\
\end{array}$ & $\begin{array}{l}\text { CTR } \\
\text { (VI) } \\
\end{array}$ & $\begin{array}{l}\text { IITR } \\
\text { (VII) } \\
\end{array}$ & $\begin{array}{l}\text { IITR } \\
\text { (VIII) } \\
\end{array}$ \\
\hline Constant Term & $1656^{* * *}(304.5)$ & $1423^{* * *}(293.8)$ & $920.3^{* * *}(262.1)$ & $962.7^{* * *}(248.7)$ & $815.1^{* * *}(276.2)$ & $847.6^{* * *}(267.3)$ & $440.1^{* * *}(29.21)$ & $499.4^{* * *}(31.13)$ \\
\hline Log Per Capita GDP & $0.405(1.998)$ & $0.243(1.821)$ & $0.278(1.652)$ & $0.350(1.595)$ & $-0.167(2.401)$ & $-0.265(2.388)$ & $-1.041(2.226)$ & $-1.322(2.185)$ \\
\hline Log Population & $5.243(5.728)$ & $0.129(6.353)$ & $10.35^{*}(5.882)$ & $10.37^{*}(5.915)$ & $-10.71(7.924)$ & $-10.51(7.994)$ & $3.688(3.601)$ & $4.190(3.651)$ \\
\hline Time Trend & $-0.816^{* * *}(0.162)$ & $-0.693^{* * *}(0.157)$ & $-0.451^{* * *}(0.139)$ & $-0.473^{* * *}(0.132)$ & $-0.378^{* *}(0.145)$ & $-0.394^{* * *}(0.141)$ & $-0.205(0.151)$ & $-0.235(0.161)$ \\
\hline TLIB_dj_KOF & $-0.072(0.045)$ & - & $-0.072 *(0.036)$ & - & $-0.015(0.039)$ & - & $-0.045(0.055)$ & - \\
\hline KOPEN_dj_CI & - & $-10.68^{* * *}(1.747)$ & - & $-5.428^{* * *}(1.835)$ & - & $-2.742(1.814)$ & - & $-3.672(2.791)$ \\
\hline Country Fixed-Effects & Yes & Yes & Yes & Yes & Yes & Yes & Yes & Yes \\
\hline Observations & 1,568 & 1,562 & 1,243 & 1,240 & 774 & 774 & 721 & 719 \\
\hline Number of Countries & 115 & 115 & 111 & 111 & 75 & 75 & 79 & 78 \\
\hline Cluster-robust Hausman Test & $22.1[0.000]$ & $10.0[0.018]$ & $11.1[0.011]$ & $12.7[0.002]$ & $14.2[0.000]$ & $13.6[0.001]$ & $15.8[0.000]$ & $10.5[0.017]$ \\
\hline R-Squared (Within) & 0.459 & 0.504 & 0.116 & 0.126 & 0.254 & 0.258 & 0.050 & 0.056 \\
\hline
\end{tabular}

Notes: TMITR: Top Marginal Income Tax Rate, TMIPTR: Top Marginal Income and Payroll Tax Rate, CTR: Corporate Tax Rate, IITR: Individual Income Tax Rate, TLIB_dj_KOF: De Jure Measure of Trade Globalization Index, KOPEN_dj_KOF: De Jure Measure of Financial Globalization Index. The robust standard errors clustered at the country level are reported. The standard errors are in parentheses and the p-values are in brackets. *****, and * indicate statistical significance at the $1 \%, 5 \%$, and $10 \%$ levels, respectively. The Cluster-robust Hausman test confirms the validity of the fixed effect estimation. 
Table 14

Baseline Regressions (The OECD Countries)

\begin{tabular}{|c|c|c|c|c|c|c|c|c|}
\hline Regressors & $\begin{array}{l}\text { TMITR } \\
\text { (I) }\end{array}$ & $\begin{array}{c}\text { TMITR } \\
\text { (II) }\end{array}$ & $\begin{array}{c}\text { TMIPTR } \\
\text { (III) }\end{array}$ & $\begin{array}{c}\text { TMIPTR } \\
\text { (IV) }\end{array}$ & $\begin{array}{l}\text { CTR } \\
(\mathrm{V})\end{array}$ & $\begin{array}{l}\text { CTR } \\
\text { (VI) }\end{array}$ & $\begin{array}{l}\text { IITR } \\
\text { (VII) }\end{array}$ & $\begin{array}{l}\text { IITR } \\
\text { (VIII) }\end{array}$ \\
\hline Constant Term & $541.6^{* * *}(167.4)$ & $596.5^{* * *}(175.2)$ & $-8.336(342.7)$ & $-11.46(358.1)$ & $896.3^{* * *}(229.1)$ & $1017^{* * *}(232.5)$ & $-121.9(161.8)$ & $-136.2(173.9)$ \\
\hline Log Per Capita GDP & $-11.59^{* * *}(2.399)$ & $-11.15^{* * *}(2.774)$ & $-11.74^{* *}(5.057)$ & $-12.33^{* *}(5.392)$ & $1.798(3.555)$ & $2.386(3.277)$ & $-17.14^{* * *}(4.658)$ & $-15.05^{* * *}(3.619)$ \\
\hline Log Population & $6.459(7.586)$ & $-10.85(8.406)$ & $-3.961(11.62)$ & $-3.754(11.54)$ & 1.069 (11.03) & $0.109(11.13)$ & $15.65(20.05)$ & $16.27(17.95)$ \\
\hline Time Trend & $-0.173^{*}(0.098)$ & $-0.201^{*}(0.104)$ & $0.098(0.202)$ & $0.094(0.211)$ & $-0.449^{* * *}(0.133)$ & $-0.503^{* * *}(0.134)$ & $0.151(0.221)$ & $0.150(0.209)$ \\
\hline TLIB_dj_KOF & $-0.143^{* * *}(0.048)$ & - & $-0.083(0.057)$ & - & $0.126^{* *}(0.062)$ & - & $-0.084(0.066)$ & - \\
\hline KOPEN_dj_CI & - & $-4.203^{*}(2.415)$ & - & $-2.259(3.176)$ & - & $-6.261^{* *}(2.415)$ & - & $-13.91^{* *}(5.442)$ \\
\hline Country Fixed-Effects & Yes & Yes & Yes & Yes & Yes & Yes & Yes & Yes \\
\hline Observations & 655 & 644 & 566 & 561 & 408 & 408 & 400 & 400 \\
\hline Number of Countries & 34 & 34 & 34 & 34 & 34 & 34 & 34 & 34 \\
\hline Cluster-robust Hausman Test & $11.4[0.009]$ & $8.49[0.036]$ & $44.4[0.000]$ & $45.6[0.000]$ & $12.1[0.006]$ & $14.1[0.002]$ & $13.7[0.004]$ & $15.2[0.000]$ \\
\hline R-Squared (Within) & 0.603 & 0.617 & 0.161 & 0.168 & 0.362 & 0.361 & 0.139 & 0.204 \\
\hline
\end{tabular}

Notes: TMITR: Top Marginal Income Tax Rate, TMIPTR: Top Marginal Income and Payroll Tax Rate, CTR: Corporate Tax Rate, IITR: Individual Income Tax Rate, TLIB_dj_KOF: De Jure Measure of Trade Globalization Index, KOPEN_dj_KOF: De Jure Measure of Financial Globalization Index. The robust standard errors clustered at the country level are reported. The standard errors are in parentheses and the p-values are in brackets. ${ }^{* *},{ }^{* *}$, and ${ }^{*}$ indicate statistical significance at the $1 \%, 5 \%$, and $10 \%$ levels, respectively. The Cluster-robust Hausman test confirms the validity of the fixed effect estimation. 
Table 15

Robustness Checks: (Including Additional Controls)

\begin{tabular}{cccccc}
\hline Robustness Exercises & Coefficient & TMITR (I) & TMIPTR (II) & CTR (III) & IITR (IV) \\
\hline Results of the Baseline Regressions & TLIB_dj_KOF & $-0.111^{* * *}(0.036)$ & $-0.089^{* * *}(0.031)$ & $0.003(0.034)$ & $-0.050(0.049)$ \\
Including Democracy Level (Index) & TLIB_dj_KOF & $-0.089^{* *}(0.036)$ & $-0.079^{* *}(0.032)$ & $0.002(0.036)$ & $-0.054(0.051)$ \\
Including Civil Liberties (Index) & TLIB_dj_KOF & $-0.108^{* * *}(0.036)$ & $-0.087^{* * *}(0.032)$ & $0.003(0.034)$ & $-0.049(0.049)$ \\
Including Institutional Quality & TLIB_dj_KOF & $-0.091^{* *}(0.036)$ & $-0.081^{* *}(0.032)$ & $0.002(0.036)$ & $-0.056(0.051)$ \\
\hline Results of the Baseline Regressions & KOPEN_dj_CI & $-9.387^{* * *}(1.517)$ & $-5.163^{* * *}(1.613)$ & $-3.268^{* *}(1.534)$ & $-5.788^{* *}(2.764)$ \\
Including Democracy Level (Index) & KOPEN_dj_CI & $-9.041^{* * *}(1.532)$ & $-4.988^{* * *}(1.601)$ & $-3.180^{* *}(1.604)$ & $-5.724^{* *}(2.889)$ \\
Including Civil Liberties (Index) & KOPEN_dj_CI & $-9.196^{* * *}(1.566)$ & $-4.967^{* *}(1.607)$ & $-3.233^{* *}(1.544)$ & $-5.777^{* *}(2.823)$ \\
Including Institutional Quality & KOPEN_dj_CI & $-9.033^{* * *}(1.522)$ & $-5.146^{* * *}(1.609)$ & $-3.151^{* *}(1.605)$ & $-5.645^{* *}(2.858)$ \\
\hline
\end{tabular}

Notes: TMITR: Top Marginal Income Tax Rate, TMIPTR: Top Marginal Income and Payroll Tax Rate, CTR: Corporate Tax Rate, IITR: Individual Income Tax Rate, TLIB_dj_KOF: De Jure Measure of Trade Globalization Index, KOPEN_dj_KOF: De Jure Measure of Financial Globalization Index. The constant term, log per capita GDP, the log population, the country fixed-effects, and the time-trend are also estimated, but their coefficients are not reported. The robust standard errors those are clustered at the country levels are in parentheses. ${ }^{* *}$ and ${ }^{* *}$ indicate statistical significance at the $1 \%$ and $5 \%$ levels, respectively. The Clusterrobust Hausman test confirms the validity of the fixed effect estimation. 
Table 16

Robustness Checks: (Excluding the Outliers)

\begin{tabular}{cccccc}
\hline Robustness Exercises & Coefficients & TMITR (I) & TMIPTR (II) & CTR (III) \\
\hline Results of the Baseline Regressions & TLIB_dj_KOF & $-0.111^{* * *}(0.036)$ & $-0.089^{* * *}(0.031)$ & $0.003(0.034)$ & $-0.050(0.049)$ \\
Excluding Extreme Units of Tax Rate Measures & TLIB_dj_KOF & $-0.137^{* * *}(0.039)$ & $-0.091^{* * *}(0.034)$ & $-0.003(0.034)$ & $-0.047(0.052)$ \\
Excluding Extreme Units of Trade Openness Measure & TLIB_dj_KOF & $-0.128^{* * *}(0.036)$ & $-0.093^{* * *}(0.036)$ & $-0.007(0.035)$ & $-0.033(0.051)$ \\
Excluding Sub-Saharan Africa Countries & TLIB_dj_KOF & $-0.159^{* * *}(0.037)$ & $-0.119^{* * *}(0.038)$ & $0.027(0.036)$ & $-0.018(0.050)$ \\
Excluding Latin American and Caribbean Countries & TLIB_dj_KOF & $-0.121^{* * *}(0.043)$ & $-0.105^{* * *}(0.032)$ & $-0.020(0.035)$ & $-0.055(0.053)$ \\
Excluding Developing East Asian Countries & TLIB_dj_KOF & $-0.115^{* * *}(0.037)$ & $-0.087^{* * *}(0.032)$ & $0.005(0.035)$ & $-0.048(0.050)$ \\
\hline Results of the Baseline Regressions & KOPEN_dj_CI & $-9.387^{* * *}(1.517)$ & $-5.163^{* * *}(1.613)$ & $-3.268^{* *}(1.534)$ & $-5.788^{* *}(2.764)$ \\
Excluding Extreme Units of Tax Rate Measures & KOPEN_dj_CI & $-7.042^{* * *}(1.452)$ & $-4.127^{* *}(1.733)$ & $-3.287^{* *}(1.514)$ & $-5.702^{* *}(2.554)$ \\
Excluding Extreme Units of Financial Openness Measure & KOPEN_dj_CI & $-9.694^{* * *}(1.638)$ & $-5.419^{* * *}(1.701)$ & $-4.188^{* *}(1.690)$ & $-6.136^{* *}(2.972)$ \\
Excluding Sub-Saharan Africa Countries & KOPEN_dj_CI & $-8.231^{* * *}(1.538)$ & $-4.797^{* * *}(1.688)$ & $-3.647^{* *}(1.607)$ & $-6.347^{* *}(2.842)$ \\
Excluding Latin American and Caribbean Countries & KOPEN_dj_CI & $-9.300^{* * *}(2.062)$ & $5.703^{* * *}(1.909)$ & $-3.559^{* *}(1.651)$ & $-5.920^{*}(3.341)$ \\
Excluding Developing East Asian Countries & KOPEN_dj_CI & $-9.720^{* * *}(1.519)$ & $-5.387^{* * *}(1.625)$ & $-3.409^{* *}(1.545)$ & $-5.820^{* *}(2.747)$ \\
\hline
\end{tabular}

Notes: TMITR: Top Marginal Income Tax Rate, TMIPTR: Top Marginal Income and Payroll Tax Rate, CTR: Corporate Tax Rate, IITR: Individual Income Tax Rate, TLIB_dj_KOF: De Jure Measure of Trade Globalization Index, KOPEN_dj_KOF: De Jure Measure of Financial Globalization Index. The constant term, log per capita GDP the log population, the country-fixed effects, and time trend are also estimated, but their coefficients are not reported. The robust standard errors those are clustered at the country levels are in parentheses. ${ }^{* * *}, * *$, and ${ }^{*}$ indicate statistical significance at the $1 \%, 5 \%$, and $10 \%$ levels, respectively. The Clusterrobust Hausman test confirms the validity of the fixed effect estimation. 
Figure 1

Benchmark Tax Rates, Financial Openness, and Trade Globalization Measures (1970-2015)

Top Marginal Income Tax Rate

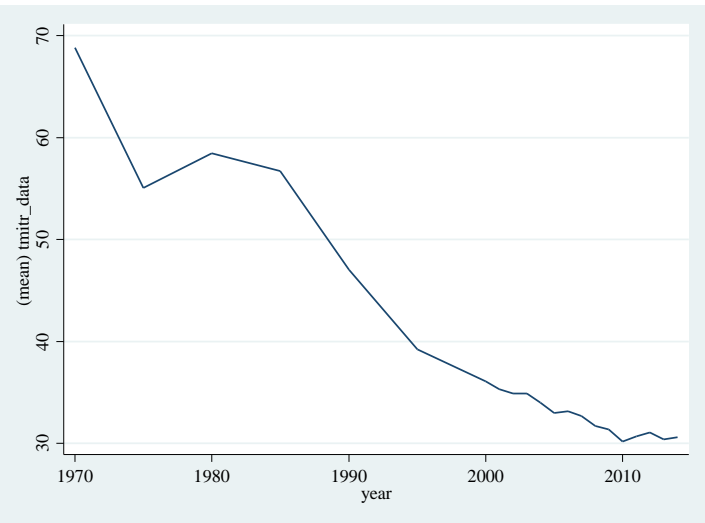

Individual Income Tax Rate

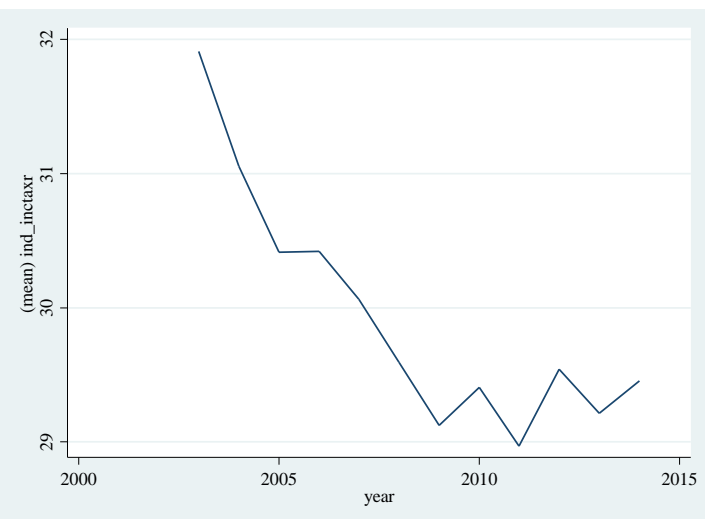

Top Marginal Income and Payroll Tax Rate

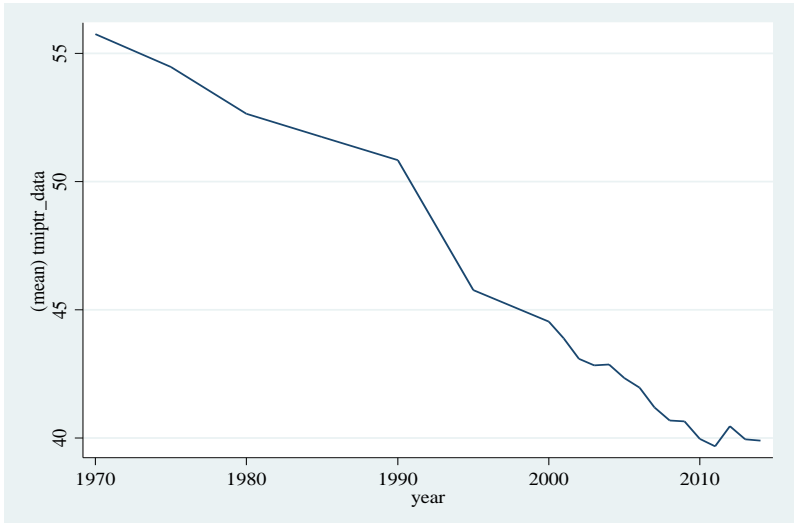

Financial Openness (Chinn-Ito Index)

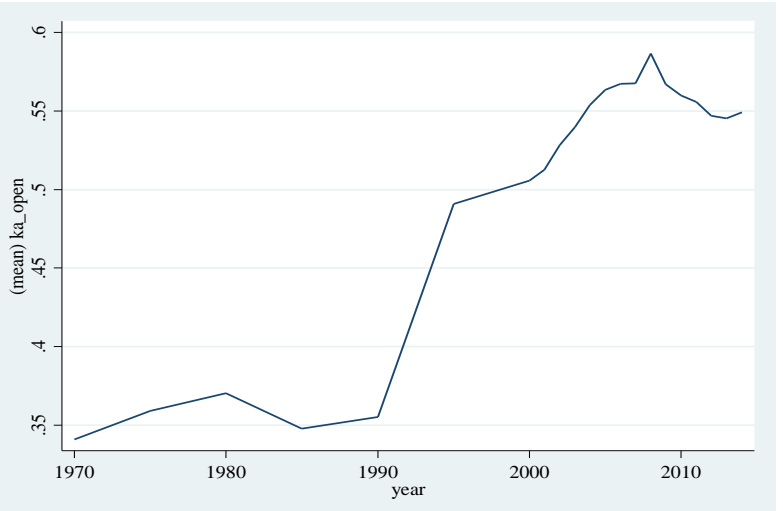

Corporate Tax Rate

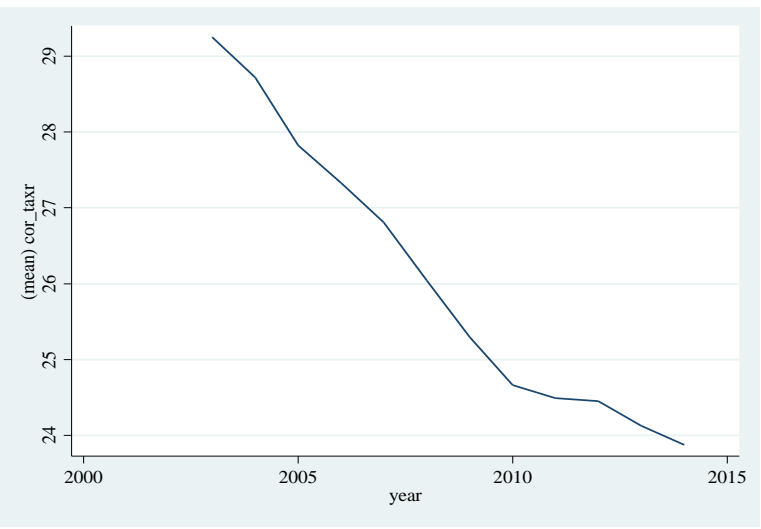

Trade Globalization (De Jure)

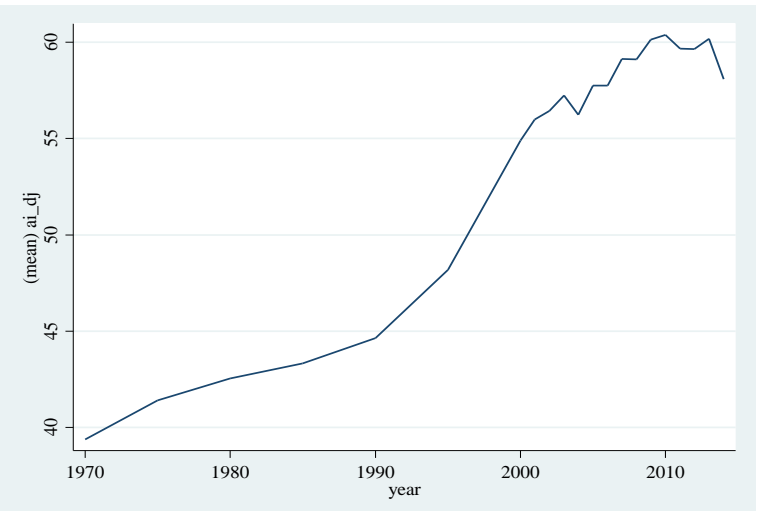


Angola, Armenia, Bangladesh, Benin, Bhutan, Bolivia, Burkina Faso, Burundi, Cambodia, Cameroon, Cape Verde, Central African Republic, Chad, Congo Democratic Republic, Congo Republic, Cote d'Ivoire, Egypt, El Salvador, Ethiopia, Gambia the, Georgia, Ghana, Guatemala, Guinea, Guinea-Bissau, Haiti, Honduras, India, Indonesia, Jordan, Kenya, Kyrgyz Republic, Laos, Lesotho, Liberia, Madagascar, Malawi, Mali, Mauritania, Moldova, Mongolia, Morocco, Mozambique, Myanmar, Nepal, Nicaragua, Niger, Nigeria, Pakistan, the Philippines, Rwanda, Senegal, Sierra Leone, Sri Lanka, Swaziland, Syria, Tajikistan, Tanzania, Togo, Tunisia, Uganda, Ukraine, Vietnam, Yemen Republic, Zambia, and Zimbabwe.

\section{The Upper-Middle-Income and the High-Income Economies (83 Countries)}

Albania, Algeria, Argentina, Australia, Austria, Azerbaijan, Bahamas, Bahrain, Barbados, Belgium, Belize, Bosnia and Herzegovina, Botswana, Brazil, Bulgaria, Canada, Chile, China, Colombia, Costa Rica, Croatia, Cyprus, the Czech Republic, Denmark, Dominican Republic, Ecuador, Estonia, Fiji, Finland, France, Gabon, Germany, Greece, Hungary, Iceland, Iran, Ireland, Israel, Italy, Jamaica, Japan, Kazakhstan, Korea Republic, Kuwait, Latvia, Lebanon, Lithuania, Macedonia FYR, Malaysia, Malta, Mauritius, Mexico, Namibia, the Netherlands, New Zealand, Norway, Oman, Panama, Paraguay, Peru, Poland, Portugal, Qatar, Romania, Russia, Saudi Arabia, Seychelles, Singapore, Slovak Republic, Slovenia, South Africa, Spain, Suriname, Sweden, Switzerland, Thailand, Trinidad \& Tobago, Turkey, the United Arab Emirates, the United Kingdom, the United States, Uruguay, and Venezuela. 